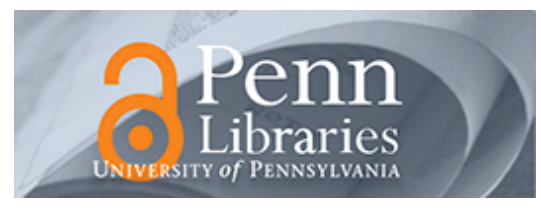

University of Pennsylvania

ScholarlyCommons

$7-2011$

\title{
Optimal Portfolio Choice over the Life-Cycle with Flexible Work, Endogenous Retirement, and Lifetime Payouts
}

Jingjing Chai

Wolfram J. Horneff

Raimond Maurer

Olivia S. Mitchell

University of Pennsylvania

Follow this and additional works at: https://repository.upenn.edu/bepp_papers

Part of the Finance Commons

\section{Recommended Citation}

Chai, J., Horneff, W. J., Maurer, R., \& Mitchell, O. S. (2011). Optimal Portfolio Choice over the Life-Cycle with Flexible Work, Endogenous Retirement, and Lifetime Payouts. Review of Finance, 15 (4), 875-907. http://dx.doi.org/10.1093/rof/rfr016 


\title{
Optimal Portfolio Choice over the Life-Cycle with Flexible Work, Endogenous Retirement, and Lifetime Payouts
}

\begin{abstract}
We derive optimal life-cycle asset allocations for a consumer who selects hours of work and retirement age, given uncertain labor income and investment returns. Shocks in labor income and capital markets interact to influence retirement and asset allocation patterns in complex ways. When workers can adjust work hours and retirement flexibly, and they also have access to lifetime payout markets, they will respond to negative labor market shocks and high stock returns by working less while young, buying more annuities, and retiring early; this flexibility enhances welfare. Further, our model is able to fit several important empirical stylized facts, such as the two peaks in retirement rates, the hump-shaped pattern of work hours, the sizeable discontinuity in consumption at retirement, and the low annuity take-ups of older households.

Disciplines

Economics | Finance
\end{abstract}




\title{
Forthcoming Review of Finance Optimal Portfolio Choice over the Life-Cycle with Flexible Work, Endogenous Retirement, and Lifetime Payouts
}

\author{
Jingjing Chai, Wolfram Horneff, Raimond Maurer, and Olivia S. Mitchell
}

We derive optimal life-cycle asset allocations for a consumer who selects hours of work and retirement age, given uncertain labor income and investment returns. Shocks in labor income and capital markets interact to influence retirement and asset allocation patterns in complex ways. When workers can adjust work hours and retirement flexibly, and they also have access to lifetime payout markets, they will respond to negative labor market shocks and high stock returns by working less while young, buying more annuities, and retiring early; this flexibility enhances welfare. Further, our model is able to fit several important empirical stylized facts, such as the two peaks in retirement rates, the hump-shaped pattern of work hours, the sizeable discontinuity in consumption at retirement, and the low annuity take-ups of older households.

\author{
Jingjing Chai \\ Finance Department, Goethe University \\ Grueneburgplatz 1 (Uni-PF. H 23) \\ Frankfurt am Main, Germany \\ e-mail: chai@finance.uni-frankfurt.de

\section{Wolfram J. Horneff} \\ Finance Department, Goethe University \\ Grueneburgplatz 1 (Uni-PF. H 23) \\ Frankfurt am Main, Germany \\ e-mail: horneff@finance.uni-frankfurt.de \\ Raimond Maurer (corresponding author) \\ Finance Department, Goethe University \\ Grueneburgplatz 1 (Uni-PF. H 23) \\ Frankfurt am Main, Germany \\ e-mail: maurer@finance.uni-frankfurt.de
}

\section{Olivia S. Mitchell}

Dept of Insurance and Risk Management, The Wharton School

University of Pennsylvania, 3620 Locust Walk, 3000 SH-DH

Philadelphia, PA 19104

e-mail: mitchelo@wharton.upenn.edu

JEL Codes: G23, G22, J26, J 32, D11

This research reported herein was performed pursuant to a grant from the US Social Security Administration (SSA) to the Michigan Retirement Research Center (MRRC) as part of the Retirement Research Consortium. Additional research support was provided by the Pension Research Council at The Wharton School of the University of Pennsylvania. Helpful suggestions were provided by participants at the 2010 Athens Household Finance Conference and the EFA 2010 meeting in Frankfurt; also we appreciate comments from Chris Carroll, João Cocco, Francisco Gomes, Roman Inderst, Michael Haliassos, Thomas Laubach, and Alexander Michalides. Opinions and errors are solely those of the authors and not of the institutions with whom the authors are affiliated.C 2011 Chai, Horneff, Maurer, Mitchell. 


\section{Optimal Portfolio Choice over the Life-Cycle with Flexible Work, Endogenous Retirement, and Lifetime Payouts}

Previous research on portfolio choice and retirement patterns has evolved from three sources. First, the finance literature has investigated how investors save and allocate their portfolios across available capital market assets, typically safe bonds and risky stocks. ${ }^{1}$ Yet most of these studies are silent on the links between labor supply and investment behavior. Second, a large public finance literature has explored how older people alter their work patterns in response to public pension system retirement incentives, but that research devotes little attention to saving and portfolio allocation patterns. ${ }^{2}$ And third, the longevity risk literature has examined how annuity payout products can help protect against outliving one's income ${ }^{3}$ but it has not yet explored how flexible labor supply might shape portfolio allocation and location decisions. The present paper seeks to unify these three strands in a model which integrates the decisionmaking process of a consumer seeking to optimally select her consumption, saving, investment patterns, work hours, and retirement age in a life-cycle context, where she has access to both capital market (stocks and bonds) and life annuities.

We contribute to the finance and pension literature by making the consumer's work/retirement decisions endogenous, as she is able to adjust both employment hours during her work-life as well as her retirement date, against the backdrop of an earnings-related benefit structure similar to the US Social Security system. We also distinguish between the date when the worker retires from her full-time job, and the date when she claims social security benefits. We also add value to the public finance literature by making investment and annuitization decisions endogenous to the lifecycle work and retirement choice. From the individual's perspective, we show how stochastic equity returns, uninsurable labor income shocks, and uncertain lifetimes help shape investment portfolio patterns and consumption paths both before and after retirement.

This is not the first analysis that makes labor supply endogenous over the life-cycle in an investment context, ${ }^{4}$ but we extend prior research by integrating flexible work hours and retirement ages with uncertain mortality and uninsurable labor income paths to show how these influence consumption, saving, and portfolio choice paths. Using a realistically calibrated life-cycle model, we derive optimal work and retirement behavior as well as

\footnotetext{
${ }^{1}$ See for instance the seminal piece by Merton (1969).

${ }^{2}$ For example, see Diamond and Mirrlees (1978) and Gustman and Steinmeier (2005).

${ }^{3}$ The classic reference is Yaari (1965).

4 See for instance Bodie, Merton and Samuelson (1992); Gomes, Kotlikoff, and Viceira (2008); and Polkovnichenko (2007).
} 
consumption and investment patterns over stocks, bonds, and payout annuities, given a realistic old-age pension structure. For the young, we show that having flexible work hours and claiming ages are consistent with substantial welfare gains of $8 \%$. The additional utility gain from having access to traditional annuities paying fixed benefits is small, but lifetime utility is greatly enhanced (by 10\%) if they can purchase investment-linked payout annuities.

We also extend the portfolio choice literature by making work patterns more flexible. Many studies have previously assumed that investors construct their portfolios independent of labor market influences, though a few do allow uninsurable labor income risk to shape household optimal consumption and investment decisions. ${ }^{5}$ The latter illustrate that portfolio equity shares optimally fall with age due to the bond-like path of labor market earnings, though they still maintain the exogeneity of labor supply. A handful of authors has embedded flexible work hours into a continuous time portfolio choice model, yet they assume unrealistically that workers can fully insure labor income risk in the capital market (i.e. that wages are perfectly correlated with a set of traded risky securities). ${ }^{6}$ A recent paper by Gomes, Kotlikoff, and Viceira (2008) endogenizes work hours over the life-cycle in a realistically calibrated portfolio choice discrete time model, yet the authors require mandatory retirement at a pre-specified age (so the worker will consume full leisure and claim Social Security benefits at the same time). Disallowing control over one's retirement age is problematic since working longer can be a key way that workers may react to capital and labor market shocks. ${ }^{7}$ In addition, deciding when to retire and claim one's Social Security benefits is one of the most important financial decisions that workers can make. Particularly in the current financial bear market, households might be able to hedge adverse capital market developments by increasing their work effort and/or working longer. Our contribution is to show how surprises in labor income and capital markets interact to influence work, consumption, and financial holdings in complex ways. When workers can adjust work hours and retirement flexibly and also have access to lifetime payout markets, negative labor market shocks and high stock returns can be offset by working less while young, buying more annuities, and claiming Social Security benefits early.

A large literature in the public finance arena explores how consumption, saving, and work patterns respond to Social Security benefit incentives, but those studies do not devote

\footnotetext{
${ }^{5}$ See for instance Benzoni, Collin-Dufresne, and Goldstein (2007), Cocco, Gomes, and Maenhout (2005), Heaton and Lucas (1997) and Viceira (2001).

${ }^{6}$ See for instance Bodie, Detemple, Otruba, and Walter (2004), Bodie, Merton, and Samuelson (1992), and Fahri and Panageas (2007).

${ }^{7}$ See for instance Coile and Levine (2010), Gustman, Steinmeier, and Tabatabai (2010), and Mitchell and Fields (1984).
} 
much attention to portfolio investment behavior. Instead, that research focuses carefully on the way in which Social Security benefits depend on and/or influence retirement behavior. For instance, Gruber and Wise (2004) and Laitner (2003) analyze the effects of Social Security taxes and benefits on retirement ages, and Gustman and Steinmeier (2005) offer an empirical analysis of retirement patterns. ${ }^{8}$ Aguiar and Hurst (2005) and Battistin, Brugiavini, and Weber (2009) focus on sharp changes in consumption around the retirement date, but they do not integrate the portfolio choice problem in their analysis. Low (2005) and French (2005) also investigate optimal consumption, saving, and labor supply patterns with stochastic and unspanned wages, but they abstract from the portfolio allocation problem.

A last research strand on which we build analyzes the impact of longevity risk on lifecycle portfolio management. This analysis demonstrates how investors chose between stocks, bonds, and payout annuities, so as to optimize their saving and consumption patterns during retirement. ${ }^{9}$ Two recent studies integrate life annuities into a realistically calibrated portfolio choice model (uninsurable labor income, uncertain life time, stochastic capital markets, and borrowing constraints) over the full life-cycle, but they do not endogenize the work hours or the retirement decision. ${ }^{10}$ They demonstrate that annuities are valuable in that they offer investors the opportunity to give up liquidity in exchange for a survival-contingent premium known as the 'survival credit'.

What remains to be done is to develop a model with uninsurable labor income, uncertainty regarding asset returns and lifetime, endogenous consumption and work hours decisions, choice of retirement date, and life annuities in the portfolio choice set. We undertake this task and compare resultant optimal behaviors from this realistically-calibrated model with several stylized facts. Our base case fits many of the stylized facts well: we obtain two peaks in retirement rates, a hump-shaped pattern of work hours, sizeable discontinuities in consumption at retirement, and low annuity take-ups by older households. While households therefore appear to do relatively well compared to model outcomes with regard to work hours, retirement pattern, and consumption, it appears that they do not allocate their financial assets optimally, compared to our model. Our welfare analysis demonstrates that improvements in portfolio choice, such as adopting an age-dependent equity exposure pattern (instead of the widely-used 60:40 constant equity/bond mix) and purchasing investment-linked payout annuities, could increase lifetime utility by quite substantial

\footnotetext{
${ }^{8}$ Other studies focus on the empirical analysis of retirement patterns; see Buchinsky, Rust, and Benitez-Silva (2000) and Benítez-Silva and Heiland (2008).

${ }^{9}$ See Milevsky, Moore, and Young (2006), Milevsky and Young (2007); Yogo (2009); and Inkmann, Lopes, and Michaelidis (2011); a literature review is provided by Horneff, Maurer, Mitchell, and Dus (2008).

${ }^{10}$ See Horneff, Maurer, Mitchell, and Stamos (2009) and Horneff, Maurer, and Stamos (2008).
} 
amounts. Nevertheless these are less important than having flexibility over work hours and retirement decisions.

\section{The Consumer's Life-Cycle Problem}

\subsection{Preferences}

We employ a discrete time model $t \in\{0, \ldots, T+1\}$ for a representative individual, where $t$ refers to the adult's age (computed as actual age minus 19 assuming the relevant lifespan starts at age 20). The individual has an uncertain lifespan and may live for a maximum of $T$ years (indexed from 1 to $T$ ). Preferences in each period are characterized by an iso-eleastic and time-separable power utility function $u_{t}\left(C_{t}, L_{t}\right)=\frac{1}{1-\rho}\left(C_{t} L_{t}^{\alpha}\right)^{1-\rho}$ defined over a composite good consisting of consumption to date $C_{t}$ and time devoted to leisure $L_{t}$. The individual's work effort is measured as a fraction of the total available time $\left(1-L_{t}\right)$, i.e. full leisure is normalized equal to one. The relative importance of leisure and consumption is governed by a modified Cobb-Douglas function, which ensures that the elasticity of substitution between consumption and leisure is equal to one. ${ }^{11}$ The parameter $\alpha>0$ governs individual preferences for leisure relative to consumption: the lower is $\alpha$, the fewer work hours the individual is willing to supply in order to boost consumption. The curvature parameter $\rho$ displays the coefficient of relative risk aversion for consumption.

The recursive definition of the corresponding value function is given by:

$$
V_{t}=\frac{\left(C_{t} L_{t}^{\alpha}\right)^{1-\rho}}{1-\rho}+\beta E_{t}\left(p_{t}^{s} V_{t+1}+\left(1-p_{t}^{s}\right) b \frac{\left(Q_{t+1}\right)^{1-\rho}}{1-\rho}\right)
$$

with terminal utility $V_{T}=\frac{\left(C_{T} L_{T}^{\alpha}\right)^{1-\rho}}{1-\rho}+\beta E_{T}\left(b \frac{\left(Q_{T+1}\right)^{1-\rho}}{1-\rho}\right)$. The parameter $p_{t}^{s}$ denotes the (subjective) probability of surviving to period $t+1$, given the individual is alive at $t$. In the last period, $p_{T}^{s}$ is equal to zero. The discount factor $\beta<1$ represents the individual's subjective time preference. $Q_{t}$ denotes bequeathed wealth and the strength of the bequest motive is controlled by the parameter $b$. In our base case, we abstract from bequest motives and set $b$ to zero, while in sensitivity analysis, we allow it to be positive. ${ }^{12}$

\footnotetext{
${ }^{11}$ Such a formulation is in line with the preference requirements of a balanced growth model; see King, Plosser, and Rebelo (1988). As noted by Cooley and Prescott (1995), a unitary elasticity of substitution between consumption and leisure is consistent with evidence that, despite average real wage having risen steadily in the US post WWII period, there has been no apparent trend in hours worked per household. Gomes, Kotlikoff, and Viceira (2008) use the same preference formulation although their analysis is silent on retirement, claiming, and annuitization decisions.

${ }^{12}$ Empirical evidence regarding the strength of the bequest motive is mixed. Hurd (1989) estimates an almost-
} 


\subsection{Financial Assets}

The individual may access financial markets by investing in three different asset classes: riskless bonds, risky stocks, and illiquid payout life annuities. The real bond gross return is denoted by $R_{f}$ and constant over time. The real gross risky stock return at time $t$ is labeled $R_{t}$ and evolves according to a geometric random walk with drift. This implies that the $\log$-returns for stocks $\ln \left(R_{t}\right) \sim \mathrm{N}\left(\mu_{\mathrm{s}}, \sigma_{\mathrm{s}}\right)$ are serially independent and identically normally distributed with mean $\mu_{\mathrm{s}}$ and standard deviation $\sigma_{\mathrm{s}}$. The return on assets is taxed according to a proportional rate $\theta^{c}$ applied to all asset income. ${ }^{13}$

We also include payout life annuities in the investment opportunity set. These are financial contracts primarily offered by life insurance companies or pension funds which, in exchange for an initial non-refundable premium, pay a pre-specified benefit income stream as long as the annuitant is alive. In the case of a fixed life annuity, currently the dominant product in the payout annuity marketplace, the survival-contingent benefits are specified for certain at the beginning of the payout period. By contrast, payments from an investmentlinked or variable annuity begin with an initial payment, and subsequent benefits are set according to an updating rule which reflects the return of an underlying portfolio which can include equities, bonds, or both. Since the annuity contract entitles the individual to a lifelong income stream, it allows the annuitant to transfer the longevity risk (i.e. the risk of outliving her assets) to the insurance company and earn the survival credit. The insurer can hedge its liabilities by pooling longevity risk across (a sufficiently large) group of annuitants. Surviving annuitants receive the reserved funds of other pool members who die. In this sense, the life annuity is a collective (or pooled) product and the redistribution of funds among surviving members can generate an extra return, referred to as the survival credit, which will exceed the return of capital market assets with similar risk profile. Nevertheless, the appeal of longevity risk protection provided by annuity contracts comes at the expense of foregone liquidity, since usually these do not provide a bequest and cannot be refunded to the purchaser.

The premium charged by the insurer for such a lifelong income stream may be derived according to the actuarial principle of equivalence:

$$
A_{t}=(1+\delta) P_{t} \sum_{s=t+1}^{T} \frac{p^{a}(t, s)}{(1+A I R)^{s-t-1}} .
$$

\footnotetext{
zero intentional bequest preference and thus concludes that most households have only accidental bequests; on the other hand, Bernheim, Shleifer, and Summers (1985) report that many older persons indicate they have a significant bequest motive.

${ }^{13}$ We do not consider tax-deferred saving accounts examined by Amromin (2003) since including these would require another state variable.
} 
Here $\delta$ is an expense or loading factor charged by the insurance company to cover administrative costs, $A I R$ is the Assumed Interest Rate, and $P_{t}$ is the first payout after the annuity is purchased. Also $p^{a}(t, s)=\prod_{t}^{s-1} p_{t}^{a}$ is the cumulative conditional survival probability that an individual age $19+t$ will survive to age $19+s$. The single-period survival probabilities $p_{t}^{a}$ are specified by a mortality table used by the insurance company which we permit to differ from the individual's subjective survival probabilities $p_{t}^{s}$. Accordingly, we can model asymmetric mortality beliefs and address the problem of adverse selection in the private annuity market. An updating rule relates the annuity payouts $P_{t+1}$ in future periods to the previous payout $P_{t}$ and the realized return $R_{t+1}^{a}$ relative to the $A I R$ of the underlying portfolio backing the annuity. Formally, the equation describing the evolution of future payouts may be recursively written as:

$$
P_{t+1}=\frac{P_{t} R_{t+1}^{a}}{1+A I R}
$$

Here $R_{t+1}^{a}=R_{f}+\pi_{t}^{a}\left(R_{t+1}-R_{f}\right)$ is the growth rate of the underlying portfolio consisting of stocks and bonds, whereby $\pi_{t}^{a}$ is the stock fraction chosen inside the variable annuity at time $t$. This equation highlights that the annuity payment rises when $R_{t+1}^{a}>1+A I R$; it falls when $R_{t+1}^{a}<1+A I R$; and it is constant when $R_{t+1}^{a}=1+A I R .^{14}$ The classic fixed life annuity is a special case, whereby the portfolio allocation inside the annuity is fully invested in bonds (i.e. $\left.\pi_{t}^{a}=0\right)$ and the AIR is set equal to the riskless interest rate (i.e. $1+A I R=R_{f}$ ).

\subsection{Labor Income and Social Security Benefits in Retirement}

Our model accounts for flexible hours during the work-life and a flexible age at which the worker can claim Social Security benefits. Our parameters are generally similar to those in the US Social Security system; that is, the worker can claim Social Security retirement benefits anytime between the 'early' claiming age (ECA; set here to age 62) and the 'latest' claiming age ( $L C A$; set here to age 70 ). The individual receives a real wage when working and decides what fraction of her available time to devote to the job. In turn, her labor supply decision $\left(1-L_{t}\right)$ then influences gross labor earnings. We allow workers to select from a menu of alternative work hour levels, since most people do not have fully flexible schedules. Labor earnings are reduced by a given fraction of expenditures related to housing $h_{t}$. Also

\footnotetext{
${ }^{14}$ A more detailed discussion of how the AIR influences payout profiles appears in Horneff, Maurer, Mitchell, and Stamos (2010).
} 
individuals must pay taxes on their labor earnings (after housing expenditures) according to the proportional rate $\theta^{l}$. Thus disposable yearly labor earnings during the work life $(\mathrm{t}<\tau$, $\tau \in[62,63, \ldots, 70])$ are given by:

$$
\begin{aligned}
& Y_{t}=\left(1-h_{t}\right)\left(1-\theta^{l}\right)\left(1-L_{t}\right) \exp (w(t)) E_{t} U_{t}, \\
& E_{t}=E_{t-1} N_{t}
\end{aligned}
$$

Here $w(t)$ is a deterministic function of wage rates with respect to age, allowing us to calibrate the empirically observed hump-shaped earnings profile. $E_{t}$ is a permanent labor earnings component with innovation $N_{t}$, and $U_{t}$ reflects a transitory shock uncorrelated with $N_{t}$. The logarithms of both $N_{t}$ and $U_{t}$ are assumed to be serially independent and identically normally distributed with mean zero and standard deviation of $\sigma_{N}$ and $\sigma_{U}$. The correlation between the innovation to the permanent component of the wage rate $N_{t}$ and the stock return $R_{t}$ is denoted by $\phi_{n}$. In our discrete time model, $\tau$ is the endogenous age at which the individual claims Social Security retirement benefits. This age is treated as both a decision variable as well as a state variable, with nine possible values from age 62 to 70 .

After claiming, the household receives lifelong benefits from Social Security (after taxes and housing costs) defined as follows:

$$
Y_{t}=\left(1-h_{t}\right)\left(1-\theta^{r}\right) \bar{Y} \zeta F_{\tau, F C A},
$$

where $F_{\tau, F C A}=\exp \left(-g_{1}(F C A-\tau)\right) I_{(\tau \leq F C A)}+\exp \left(-g_{2}(F C A-\tau)\right) I_{(\tau>F C A)}$. The Social Security replacement rate $\zeta$ is based on lifetime average earnings, and the age when the worker can claim full benefits is denoted by FCA. ${ }^{15}$ The average lifetime earnings level is approximated by $\bar{Y}=\left(\sum_{t=1}^{K}(1-\bar{L}) \exp (w(t)) / K\right) E_{K}$, whereby $K$ denotes the period when the individual attains her full claiming age and $1-\bar{L}$ stands for the average fraction of available time worked during her work-life. ${ }^{16}$ Social Security benefits are taxed at rate $\theta^{r}$, which might be lower than the wage tax rate to account for progressive taxation. $I$ is an indicator function which identifies whether the individual claims at, later, or prior to the $F C A$. The factor $F_{\tau, F C A}$

\footnotetext{
${ }^{15}$ We use the term Full Claiming Age (FCA) since we distinguish retirement from claiming decisions. This differs from the terminology used by the US Social Security Administration, who employs the term Full Retirement Age (FRA).

${ }^{16}$ This is a reasonable approximation of the average indexed monthly earnings (AIME) concept used by the US Social Security Administration which uses an average of the worker's highest 35 years of earnings to calculate benefits. Our formulation saves a state variable yet takes into account the fact that people with relatively high average career earnings will perceive a lower replacement rate from Social Security benefits (i.e., benefits from Social Security benefits as a percent of the worker's average salary) compared to lower earners.
} 
depends on the $F C A$, the endogenous claiming age $\tau$, the reduction rate $g_{1}$, and the delayed claiming credit rate $g_{2}$ (here $g_{1}$ and $g_{2}$ are positive constants). If the worker claims prior to the $F C A, \quad F_{\tau, F C A}$ functions as an actuarial reduction factor permanently reducing her benefit payments. On the other hand, if she claims later than the $F C A$, her lifelong benefits are increased by the delayed retirement credit factor $F_{\tau, F C A} \cdot{ }^{17}$ In our model, we assume that people claim retirement benefits and move to full leisure at the same age, as Coile, Diamond, Gruber, and Jousten (2002) indicate that this is, in fact, what most people actually do. Additionally, the work-leaving decision is permitted to differ from the date of claiming Social Security benefits. We denote individuals as retired if they leave their full-time jobs. Workers can retire from full-time jobs without claiming Social Security benefits as long as they live on saving and part-time jobs.

From the individual's viewpoint, the Social Security system is analogous to a mandatory defined benefit pension scheme with lifelong annuity payments. In this way, private life annuities and Social Security benefits are comparable since both provide lifelong income; moreover individuals can 'roll their own' personal defined benefit scheme by resorting to the private life annuity market.

\subsection{Wealth Transition and Optimization}

The individual decides each period how to allocate her available cash on hand $W$ to consumption $C_{t}$ and liquid saving compromised by bonds $B_{t}$ and stocks $S_{t}$, and the amount $A_{t}$ of newly-purchased life annuities. The budget constraint becomes:

$$
W_{t}=S_{t}+B_{t}+A_{t}+C_{t} .
$$

With this investment and consumption strategy, next period's wealth $W_{t+1}$ consists of after-tax financial wealth (including stocks and bonds), annuity payments, labor income during the work-life and Social Security benefits after claiming. This is given by:

$$
W_{t+1}=\left(S_{t} R_{t+1}^{s}+B_{t} R_{f}\right)-\theta^{c}\left(\left(S_{t} R_{t+1}^{s}+B_{t} R_{f}\right)-\left(B_{t}+S_{t}\right)\right)+P_{t+1}+Y_{t+1}
$$

where $P_{t+1}$ is the sum of annuity payments received from all previously-purchased annuities Here $Y_{t+1}$, which below we call labor income, is defined in equations (4) and (5), i.e. net labor earnings prior to claiming, and Social Security benefits after claiming. If the individual dies, her estate is given by her remaining liquid savings in bonds and stocks:

$$
Q_{t+1}=\left(S_{t} R_{t+1}^{s}+B_{t} R_{f}\right)-\theta^{c}\left(\left(S_{t} R_{t+1}^{s}+B_{t} R_{f}\right)-\left(B_{t}+S_{t}\right)\right) .
$$

The recursive evolution equation for the sum of after-tax payouts from all previous annuities

\footnotetext{
${ }^{17}$ Other details of the Social Security rules are not considered here such as the earnings test for those who still work and hence have labor income after claiming Social Security benefits.
} 
purchased can be written as: ${ }^{18}$

$$
P_{t+1}=\left[\frac{P_{t}}{(1+A I R)}+A_{t}\left((1+\delta) \sum_{s=t+1}^{T} \frac{p^{a}(1, s)}{(1+A I R)^{s-t-1}}\right)^{-1}\right]\left(\left(R_{f}+\pi_{t}^{a}\left(R_{t+1}-R_{f}\right)-1\right)\left(1-\theta^{c}\right)+1\right),
$$

The individual's optimization problem is now to maximize the utility in (1) with respect to the appropriate asset allocation between bonds, stocks, and life annuities (including the optimal weight to stocks within the annuity), consumption/saving, leisure, and the decision when to claim Social Security benefits:

$$
\max _{C_{t}, L_{t}, S_{t}, B_{t}, A_{t}, \pi_{t}^{a}, \tau} V_{t}
$$

We rule out short-selling in stocks and bonds (inside and outside the annuity) and preclude the household from borrowing against future labor, pension, and annuity income by imposing the non-negativity restrictions: $A_{t}, \pi_{t}^{a},\left(1-\pi_{t}^{a}\right), S_{t}, B_{t} \geq 0$.

There are five state variables in the model: cash on hand $W_{t}$, annuity payouts from previously purchased annuities $P_{t}$, permanent labor earnings $E_{t}$, the retirement age $\tau$, and age $t$. To reduce the problem by one state variable, we normalize the continuous state variables cash on hand and annuity payouts with the permanent labor earnings component. Next we discretize the (normalized) continuous state variables and solve the optimization problem by backward induction in a four-dimensional state space. For computations, we use a $40(W) \times 30(P) \times 42(t)$ grid space before and a $40(W) \times 30(P) \times 39(t) \times 9(\tau)$ after $E C A$. For each grid point we evaluate the value functions using Gaussian quadrature integration and cubicspline interpolation.

\subsection{Model Calibration}

The individual's lifespan is modeled from age 20 to $100(T=81)$. In our base case, preference parameters are set to standard values in the life-cycle literature, namely a coefficient of relative risk aversion of $\rho=5$ and a time discount factor of $\beta=0.97 .{ }^{19}$ The oneperiod survival rate $p_{t}^{s}$ which enters into the utility function is calculated using the US 1996

\footnotetext{
${ }^{18}$ Here the annuities are held in a non-tax qualified account and interest earnings are taxed as capital gains at a rate below the tax rate on labor earnings but higher than the Social Security tax rate (i.e. $\theta<\theta<\theta$ ). This is an approximation to the exclusion ratio approach implemented by the US tax authority adopted for computational simplicity; for more detail on annuity taxation see Brown, Mitchell, Poterba, and Warshawsky (1999) and Milevsky (2006).

${ }^{19}$ Samwick (1998) reports that median time preference rates for US households are between 3 and \%, which implies a discount factor $\beta$ of between 0.971 and 0.962 . Therefore, $\beta=0.97$ is consistent with Samwick's (1998) empirical finding.
} 
population 2000 table for females. We set the leisure preference parameter $\alpha$ equal to 1.3 which is higher than 0.9 used by Gomes, Kotlikoff, and Viceira (2008). Yet, by doing so, the optimal behaviors resulting from our model, such as retirement behavior, consumption profiles and work hours, fit the empirical findings well. Later, in the sensitivity analysis, we vary both the utility parameters for risk aversion and leisure.

The analysis also sets the mean real equity log-return at $\mu_{\mathrm{s}}=3.01 \%$ and the corresponding volatility parameter $\sigma_{\mathrm{s}}=19.34 \%$, equivalent to a yearly expected gross real return of 1.05 and standard deviation of $20.5 \%$; the assumed real riskless rate $R_{f}$ is 1.02 . While the equity risk premium of $3 \%$ is one percentage point lower than the value typically used in other life-cycle studies (e.g., Cocco, Gomes, and Maenhout 2005), we believe that this lower value is a more reasonable expectation for the future after the recent financial crisis. ${ }^{20}$ (In sensitivity analysis, we also consider a case with a higher equity risk premium.)

The calibration of the wage rate process follows Gomes, Kotlikoff, and Viceira (2008), reflective of middle-income households. Here a deterministic age-dependent component $^{21}$ is combined with permanent and transitory wage rate shocks using standard deviations equal to $\sigma_{N}=10.95 \%$ and $\sigma_{U}=13.89 \%$ (from Cocco, Gomes, and Maenhout 2005). The correlation between stock returns and permanent earnings shocks $\phi_{\mathrm{n}}$ is set in the base case to zero, consistent with Cocco, Gomes, and Maenhout (2005). Returns on assets are assumed to be taxed at 20\%; labor earnings are taxed at 30\% following Gomes, Kotlikoff, and Viceira (2008). Housing-related expenditures are modeled as in Gomes and Michaelides (2005).

We assume that the worker has an available time of 100 waking hours per week and has flexibility to choose her level of work intensity. There are seven job types: 60, 50, 40, 30, 20,10 , and 0 work-hours per week, implying $\left(1-\mathrm{L}_{\mathrm{t}}\right) \in[0.6,0.5,0.4,0.3,0.2,0.1,0]$. The average work effort $1-\bar{L}$ used to calculate Social Security benefits is equal to 0.4 , which is in line with an average lifetime work effort of 40 hours per week. This corresponds with the particular average work hours of a high school graduate reported by American Time Use Survey (US Department of Labor, 2010). The Social Security benefit structure is similar to that in effect in the United States. The benefit replacement rate $\zeta$ is set to 0.52 as per Mitchell and Phillips (2006); the actuarial reduction rate for claiming early old age benefits is

\footnotetext{
${ }^{20}$ As per the annual returns for the value-weighted stock market index portfolio for US-stocks and bonds with a duration of one year (provided by CRSP), we calculate the annual equity risk premium for the postwar period 1950-2008 and for the period 1950-2004; the difference is $-0,86 \%$, which corresponds to our assumption.

${ }^{21}$ More precisely, the earnings function reported in Fehr, Jokisch, and Kotlikoff (2006) equation (9) with parameter $\lambda=0$ is used, which results for middle-income workers $\mathrm{w}(\mathrm{age})=\exp \left(4.47+0.033^{*}\right.$ age $-0.00067^{*}$ age $\left.{ }^{2}\right)$; this produces a hump-shaped pattern for wage rates.
} 
$g_{1}=0.0713$ and the crediting rate for claiming delayed benefits is $\mathrm{g}_{2}=0.077$ as in Buchinsky, Rust, and Benitez-Silva (2000). Workers can claim Social Security benefits between age 62 and 70, whereby the FCA is set to 65. Social Security benefits are taxed at a rate of $15 \%$ as in Gomes, Kotlikoff, and Viceira (2008).

To price the life annuities, the assumed interest rate AIR is set to $2 \%$, the expense loading factor $\delta$ is $2.38 \%$ (in line with industry leaders such as Vanguard), and we use conditional survival probabilities $p_{t}^{a}$ from the US 1996 female annuitant 2000 mortality table to account for potential adverse selection in the voluntary annuity market. In our base case we assume that the worker only has access to life annuities with fixed payouts. Later on, for the welfare analysis, we also take the investment-linked payout annuities into account.

\section{Baseline Results}

In what follows, we present the results for our base case where the individual can elect retirement age, work/leisure intensity, the level of consumption/savings and the portfolio allocation across stocks, bonds, and fixed life annuities. To do so, we use the optimal feedback controls obtained from the numerical optimization model and compute expectations using 10,000 Monte Carlo simulations. In Section 2.1 we discuss patterns of expected optimal consumption, labor income, and work hours. Section 2.2 analyzes the worker's portfolio choice. Section 2.3 depicts retirement behavior, optimal Social Security claiming ages, and consumption changes at retirement. We conclude this section by analyzing the heterogeneous interactions between exogenously-realized labor and capital market outcomes, on the one hand, and, on the other, behaviors including consumption, saving, work effort, and retirement.

\subsection{Consumption, Saving and Work Hours Profiles}

Figure 1A traces paths for average consumption, labor income after tax and housing expenditures, payment from private life annuities, and liquid saving/wealth patterns by age, as well as new annuity purchases. In addition, the function for leisure and consumption which enters utility is also plotted. All values are normalized by the worker's first-year labor income. Panel 1B displays the pattern of average work hours for different age groups, as well as the distribution of job types. We classify the job types by work intensity into three categories: overtime work (more than 40 work hours per week); full-time work (40, 30 hours per week); part-time work and non-job respectively (less than 30 hours per week).

\section{Figure 1 here}

Panel 1A shows that in the first five years of the life-cycle, net labor income tracks 
consumption closely, and only a small amount of savings is accumulated. This is consistent with the model's assumption that agents are liquidity constraint and cannot increase consumption through borrowing against future labor income. Since wage rates are low early in life, younger workers have little incentive to increase labor earnings through overtime work.

From the age of 25 until the age of 45, households substantially increase their saving. The expected amount of liquid assets peaks at the age of 52, where it amounts to approximately nine times first-year labor income. Average labor income follows a humpshaped pattern from age 20 until age 65 and reaches its highest level at around age 45 . After that people gradually receive less labor income until age 65 , after which point the labor income stream "recovers" and displays a V-shaped pattern. This differs from other life-cycle studies such as Campbell and Viceira (2001) and Cocco, Gomes, and Maenhout (2005), which do not report the recovery but rather show a substantial drop of labor income at the exogenous retirement age (usually defined as age 65).

The reason for this $\mathrm{V}$-shaped pattern of labor income has to do with the interaction between endogenous work effort and flexibility in claiming Social Security benefits. Figure 1B shows that, after age 25 when wage rates are growing, households increase their work hours and many of them work overtime. This results in rising labor income. For the 30-34 age group, households average 48 hours at work and $80 \%$ work overtime. Later, they gradually curtail labor effort and fewer households work overtime. In middle age, the decreasing work hours are compensated by still-growing wage rates, i.e. net average labor income is relative stable and high during this time. After that, around age 50, households start to retire from full time jobs and sharply decrease average work hours. In the age group 60-64, average work effort is about 27 hours per week, and $35 \%$ of households work part-time. In addition, as we discuss in more detail in the next section, many households do not claim their Social Security benefits early but instead they wait until age 65 to avoid reductions for claiming early retirement benefits. Hence during the early 60 s, due to low work effort and low wage rates, labor income is relatively low. From age 65 on, an increasing number of workers claims Social Security benefits calculated based on full-time work and therefore they are higher than the last labor income stream from part-time work. Again, this helps drive the V-shaped pattern of labor income.

Turning to liquid wealth, Figure 1A shows that from their mid-50s, households start to run down their liquid wealth to support consumption which grows until the mid-60s. Especially between ages 60 and 70, many households who retire from full-time work and 
delay claiming Social Security benefits, financing most of their consumption by withdrawing from their liquid saving. For example, at age 60, the mean liquid wealth is about 6.9 of firstyear labor income and only 1.1 at age 70 . Compared with the peak of assets at age 52, this is an asset-exhaustion of about $24 \%$ as of age 60 , and $85 \%$ until age 70 . Besides financing consumption, some liquid wealth is used to build up a "second income" from annuity purchases to supplement Social Security benefits in retirement. After the age of 80 , when liquid savings are depleted, the individual relies mainly on Social Security benefits and secondarily on annuity payments.

To capture the empirical pattern of work hours, we use the Panel Study on Income Dynamics (PSID) data in 2006. Average work hours are calculated by age for US middle income class workers (defined here as yearly earnings between $\$ 25,000$ and $\$ 100,000$ ). The data shows an average work effort (up to age 65) of 39.1 hours per week, close to the 39.4 hours predicted by the model. In addition, the pattern for work hours clustered by age is also hump-shaped with a peak in the mid-thirties as predicted by the model (Appendix B). ${ }^{22}$ Accordingly, the model generates a relatively realistic labor supply pattern. Overall, individuals who can adjust their work hours profit from working harder early in life and build up reasonable asset accumulations, used to enjoy more leisure at older ages, and receive delayed credits from Social Security.

The consumption profile also shows a hump-shaped pattern. Consumption grows during the work-life: early on, growing spending levels are financed by rising labor earnings, and later by drawing down accumulated assets. Around age 65, when most households increase leisure substantially and start to claim Social Security benefits, consumption drops sharply and keeps decreasing thereafter. In other words, older households in retirement are more willing to substitute purchased goods for leisure time once this is feasible. ${ }^{23}$ Consistent with the prediction of the permanent income hypothesis, the expected value of the composite good defined over consumption and leisure $F=C \cdot L^{\alpha}$ which enters into the utility function remains quite smooth over the life-cycle. After the age of 70 , when individuals enjoy full leisure, their effective rates of time preference become higher (because of increasing mortality). Hence the willingness to trade off future for current consumption is reduced, which explains why individuals devote all their entire income to consumption late in life.

The sharp decline in consumption at retirement is in contrast to other life-cycle studies which do not endogenize work hours and retirement flexibility, nor the age at which people

\footnotetext{
${ }^{22}$ Similar results are also reported by Low (2005).

${ }^{23}$ This is in line with empirical evidence regarding pre/post consumption and leisure patterns reported in Aguiar and Hurst (2005).
} 
can claim their Social Security benefits (e.g. Campbell and Viceira 2001; Cocco, Gomes, and Maenhout 2005). Their results indicate very smooth consumption patterns between pre- and postretirement. ${ }^{24}$ Yet a large empirical literature documents an important drop in spending at retirement, for instance, Bernheim, Skinner and Weinberg (2001) for U.S. households, Banks, Blundell, and Tanner (1998) for the U.K., and Battistin, Brugiavini, Rettore, and Weber (2009) for Italy. This discrepancy between standard life-cycle model predictions and empirically observed drops in consumption at retirement has been referred to as the 'retirement consumption puzzle'. By contrast in our model, agents endogenously reduce their expenditure levels around the time of retirement at a fast pace, suggesting that the so-called 'consumption puzzle' described by many analysts may, in fact, not be a puzzle at all. More details on the retirement behavior and consumption pattern are provided in Section 2.3.

\subsection{Portfolio Allocations}

Next we explore expected household asset allocation patterns by age. The stacked portion of the graph in Figure 2 depicts the expected amount invested by age in stocks (bottom), bonds (middle), and fixed payout annuities (top), as a multiple of first-year labor income. In addition, the figure illustrates the trajectory of the corresponding asset weights, reported as a percent of total wealth, defined as liquid holdings in stock and bonds plus the present value of annuity payments.

Figure 2 here

The graph indicates that the individual will invest a large fraction of saving in stocks along the mean path over the life-cycle. Early in the work-life, stocks are the most important form of investment; until the mid-30s, the individual invests $100 \%$ in stocks. This is because future labor income can be thought of as a high implicit bond position, so investors will seek to diversify their overall portfolios consisting of both human and financial wealth (Campbell, Cocco, Gomes, and Mahenhout 1999). By investing in stocks, the worker creates a buffer against future labor income shocks. In midlife, when financial wealth is increasing relative to expected future labor income the investor shifts the asset allocation from risky stocks toward safer bonds. Around the age of 57, the fraction invested in stocks falls to its lowest level, approximately $65 \%$. Thereafter, the individual is exposed to declining labor income risk as the number of work years remaining falls and the individual becomes eligible to claim Social Security benefits. The fraction invested in stocks then increases again, until age 65 . Until retirement, the fraction invested in stocks is higher than those reported in prior studies that

\footnotetext{
${ }^{24}$ The study by Gomes, Kotlikoff, and Viceira (2008) also reports a discontinuity in consumption at retirement but provides no further discussion of the magnitude of this drop.
} 
rule out endogenous work effort and claiming dates. ${ }^{25}$ The fact that households may react to adverse stock market shocks by delaying retirement and claiming permits them to hedge capital market risk.

It is interesting that fixed payout annuities do not appear in workers' optimal portfolios until their mid-50s. This is because these are unattractive compared to bonds, due to high loadings in pricing and their inherent illiquidity. As individuals are more likely to die at older ages, the survival credit rises above the bond rate. As a result, starting around their mid$50 \mathrm{~s}$, investors gradually switch from liquid bonds to fixed annuities. At age 66, the allocation to bonds is close to zero, whereas the fraction of total wealth invested in annuities is $25 \%$. Thereafter, annuities also start to crowd out stocks to take advantage of the further increasing survival credit. Around age 80 , almost the entire portfolio of financial wealth is invested in fixed annuities which provide a lifelong 'Social Security-like' income stream. At that time, annuity wealth reaches its maximum and is approximately equal to first-year labor income. Yet the resulting payments from these annuity holdings are not large, amounting to only about $7 \%$ of total income ${ }^{26}$ at age 80 . Accordingly, in old age, people are expected to rely mainly on Social Security benefits.

This pattern of optimal asset allocation to life annuities for older households is in line with empirical evidence. For instance, the U.S. Social Security Administration (2010, Table $10.1)$ reports that about $11.2 \%(9.4 \%)$ of the income for the $80+(65+)$ population results from private pensions and annuities. To compare these numbers with the prediction from our model, we calculate the average fraction of total income generated by annuities for the 10,000 simulated households. For households age $80+$, the model generates an annuity income of $11.6 \%$ (and $8.4 \%$ for those age $65+$ ). The reason for the relatively low annuity income is that a mandatory Social Security system with annuity-like old age benefits crowds out the demand for additional private life annuities.

Optimal asset allocation patterns generated by our model suggest that younger investors will hold more risky assets than older investors; for instance, between ages 20-30, the average stock fraction rises to $100 \%$, with declines after that. A high and then falling stock weight by age is in line with several previous normative studies including Cocco, Gomes, and Maenhout (2005) and Gomes, Kotlikoff, and Viceira (2008), and it is also consistent with financial planning advice (Malkiel 1996). Nevertheless, this pattern is contrary to much empirical evidence. For instance, Gomes and Michaelides (2005) show that the average share of financial wealth invested in stocks over the life-cycle is relatively constant, at about $60 \%$,

\footnotetext{
${ }^{25}$ For example, Cocco, Gomes, and Maenhout (2005) and Gomes, Kotlikoff, and Viceira (2008).

${ }^{26}$ Total income is defined as sum of labor income, annuity payments, and asset income.
} 
in the 2001 Survey of Consumer Finances. In this paper, our goal is try to find out how much the actual behavior of households differs from their expected behavior described by our model, rather than match the empirical findings. ${ }^{27}$

\subsection{Social Security Claiming, Retirement Behavior, and Consumption at Retirement}

Next we explore when individuals start to retire from full time work and when they claim Social Security benefits. We also provide more details about the consumption changes around retirement. Using the 10,000 simulated households, Table 1A traces out the fraction of households electing to claim Social Security benefits and retire, for each age between 62 and 70. Here we differentiate between claiming and retirement ages: when a household decides to claim the Social Security benefit, it moves to full leisure at the same time. Yet a household could retire before claiming Social Security benefits. Following the empirical work by Gustman and Steinmeier (2005) and Bernheim, Skinner and Weinberg (2001), we denote individuals as retired if they work 20 hours or fewer per week. This allows us to compare the model's results with respect to retirement ages and consumption patterns around retirement with empirical evidence in the literature. Moreover, we also show the expected change in (log average) consumption at different retirement ages. As in Bernheim, Skinner and Weinberg (2001), we measure the size of consumption change as the difference in log average spending two years after and prior to retirement.

\section{Table 1 here}

Panel 1A shows that workers claim Social Security benefits between the ages of 64 and 68 , with a mean age of 66.5 . Only 140 out of 10,000 simulated households optimally claim before 65 ; these are the marginal households willing to accept much lower lifelong benefits in exchange for early claiming. In fact, the majority of households will wait and enjoy the credit for delaying their claiming decision. In contrast, retirement from full-time work begins much earlier, at age 62 ; by age 66 , all have retired. On average, retirement occurs 2.7 years earlier than claiming (age 63.8 versus 66.5). Accordingly, the model generates two retirement peaks: the first is at age 62 where one-third of the households retire, and the second

\footnotetext{
${ }^{27}$ Future work will explore extensions that can narrow this remaining gap between the theory and this stylized fact. A possible explanation for the difference may be lack of financial literacy and inertia (Lusardi and Mitchell 2007). Other efforts to match the empirically observed asset allocation include Gomes and Michaelides (2005) who introduce a fixed entry cost for stock market participation and assume a higher correlation between stock returns and labor income. Polkovnichenko (2007) postulate additive habit preferences instead of a standard CRRA utility function. Nevertheless, the latter studies focus only on matching the asset allocation fractions, while they abstract from other behaviors including consumption change around retirement, work hours, and claiming age. Finally, incorporating entry costs and habit preferences would require at least one additional state variable, which would greatly increase the computational burden given the already-high numerical dimensions of our model.
} 
is at age 65 (30.1\% retire). This pattern is consistent with Gustman and Steinmeier's (2005) findings using the Health and Retirement Study where they note two retirement spikes: a main one at age 62 , and a smaller one at age 65 . Thus our model does a credible job in replicating at least the general pattern of the empirically observed retirement distribution.

Panel 1A also shows the change in consumption between the two years prior to and after retirement. All retirement groups suffer a negative change in consumption, which is much higher for households electing to retire late than for those who retire early $(-35 \%$ for retirees at age 66 versus $-5 \%$ for retirees at age 62 ). Panel 1B displays summary statistics for the change in $(\log )$ average consumption. The expected change is $-19 \%$ and the median decline is $-20.3 \%$, with a high standard deviation of $18.9 \%$. In addition, the results show a positive correlation of 0.43 between the change in consumption and wealth at retirement (liquid saving). Moreover, individuals in the lowest wealth quartiles show a much greater consumption drop, of $35 \%$, compared to the $7.5 \%$ drop for those in the highest wealth quartile

Such a sharp drop in spending at retirement is consistent with empirical studies. Bernheim, Skinner, and Weinberg (2001) report for US households a mean change in log consumption at retirement of $-14 \%$ and a standard deviation of $42 \%$, in data from PSID and the Consumer Expenditure Survey. Thus our life-cycle model with rational forward-looking optimization produces a comparably-sized consumption drop as in the data. In addition, and consistent with the prediction of the model presented here, Bernheim, Skinner and Weinberg (2001) (p. 846) report that " $(\ldots)$ a higher wealth ratio is associated with a smaller decline in consumption". Our model's results are also in line with the empirical study by Aguir and Hurst (2005) which use a rich dataset from the Continuing Survey of Food Intake of Individuals allowing them to disentangle consumption from expenditure. They find a decline in expenditures for nondurable consumption at retirement by $17 \%$ and show that this decline is accompanied by a large increase in time spending on food production. While our model framework does not permit a detailed analysis of time/consumption patterns as in Aguir and Hurst (2005), our general results are in line with their findings. At retirement, households are highly willing to substitute consumption expenditures for leisure time. In this sense, we have demonstrated that the so-called 'retirement consumption puzzle' may actually not be a puzzle at all, if leisure preferences, flexibility in work hours, and retirement ages are properly integrated in the model.

\subsection{Heterogeneous Responses to Shocks}

Next we illustrate interesting interactions between exogenously-realized labor and 
capital market outcomes, on the one hand, and, on the other, behaviors including consumption, saving, work effort, and retirement. The impact of shocks is examined for the scenario where consumers have flexible work hours and access to fixed annuity markets.

Figure 3 illustrates average consumption/saving patterns (3A and $3 \mathrm{~B}$ ), wage rates (3C), work effort (3D), and average stock returns (3E) computed only for individuals who elect to retire at age $62(3,310$ out of 10,000 samples $)$ and age $66(1,310$ out of 10,000 samples). Generally individuals who retire later are those who experienced a positive permanent wage shock early in life as well as a relatively poor stock returns (3C and 3D). Higher wage rate paths produce higher Social Security benefits, both directly and via the delayed retirement credit. This generates both substitution and wealth effects: higher wages make leisure more expensive and hence induce more work, counteracted by the fact that higher-paid people have more wealth which prompts greater leisure consumption. For our preference formulation, individuals with higher wage rate paths also work more, indicating that the substitution effect dominates. ${ }^{28}$ To compensate for later retirement and high work effort when young, households have high consumption levels, build up relatively little financial wealth, and show a high drop in consumption at retirement; they buy fewer annuities and only later in life (3B). This can be explained by the fact that, because of high labor income trajectories, these households expect relatively large Social Security benefits so they need not amass much wealth in stocks, bonds, and annuities. At age 66, households decide to retire completely from full-time work, enjoy full leisure, and claim the Social Security benefit immediately (3D). This induces a positive jump in leisure. Therefore, to keep the intertemporal marginal utility of consumption constant, as a reaction to an upside jump in leisure, consumption at retirement drops by $35.3 \%$ (Table 1A). ${ }^{29}$ Again, we show that the size of consumption drop is positively associated with the level of financial wealth at retirement.

Figure 3 here

By contrast, those who experience negative wage shocks early in life tend to work less, retire from full-time jobs as early as possible, but then they delay claiming Social Security benefits. This is because such individuals compensate for their lower wage rates by taking more leisure earlier in life and also electing earlier retirement. Interestingly, households with low wage profiles, low work effort, and early retirement, also typically have above-average stock market performance (3D). They then can build up relatively higher financial wealth and buy more/earlier annuities. Their main retirement income source is then payouts from private

\footnotetext{
${ }^{28}$ A positive relation between wages and expected optimal labor supply is noted by Bodie, Detemple, and Rindisbacher (2009) for the same set of preferences. Blundell and MaCurdy (1999) also finds out that the wealth effects in labor supply are smaller than substitution effects.

${ }^{29}$ See also Battistin, Brugiavini, and Weber (2009).
} 
annuities, with less coming from Social Security benefits. Accordingly, high stock market returns lead households to retire early. They gradually switch from full-time to part-time work. This implies a gradual change in leisure and an appropriately small consumption change at retirement (Table 1A; Figure 3D).

\section{Sensitivity Analysis}

The model also allows us to quantify the complex interactions of household optimal behavior on work hours, retirement, consumption, and asset allocation decisions. Thus it is of interest to assess whether our base case results vary with alternative formulations. To this end, we explore several alternative formulations of key utility parameters, namely risk aversion, the value attached to leisure, and the bequest motive. We also examine three other variations, namely the expected equity risk premium, the correlation of equity returns with labor income, and the age at which full Social Security benefits can be claimed. Of particular interest are the effects on work hours, retirement ages, and consumption changes at retirement, all summarized in Tables 2, 3 and 5. In addition, we evaluate the effects on asset allocation patterns in Table 4. In all instances, base Case (1) is the point of reference, where the worker can elect flexible work hours, an endogenous claiming age, and an endogenous retirement age; she also has access to stocks, bonds, and fixed payout annuities. Variants include Case (2) which boosts risk aversion to $\rho=7$. In Case (3) we make $\alpha$ age-dependent to allow the utility of leisure to deteriorate with poorer health at older ages (motivated by Buchinsky, Rust, and Benítez-Silva, 2000). The leisure parameter is given by $\alpha(t)=1.9$ $1 /(1+t / 60)$, where $t$ is the period. Case (4) reduces the consumer's leisure preferences to $\alpha=$ 0.9 as in Gomes, Kotlikoff, and Viceira (2008). In Case (5) we introduce a bequest motive with $b=2$. Case (6) incorporates a correlation of 0.2 between stocks returns and permanent labor income, and Case (7) increase the equity risk premium to 5\%. For our final case (8), we increase the age at which full benefits from Social Security can be claimed $(F C A=67)$.

Tables 2-5 here

Preference Parameters: We first explore the impacts of different preference parameters on labor supply, retirement, consumption, and investment decisions. Table 2 displays labor supply patterns where the 'point of reference' individual begins working about 40 hours per week, and in her mid-30's peaks at just under 50 weekly hours; thereafter her hours fall gradually until retirement in the late 60's. All such persons have retired from fulltime work after age 66 (see Table 3). For the risk-averse individual (Case 2), work hours between ages 30-60 are similar to those in the reference case, but they are higher for young 
workers until age 30 and lower before retirement. This is because greater risk aversion increases young workers' desire to build a buffer stock against uninsurable labor income risk (due to a precautionary savings motive). Hence they work more early in life and use their higher income to accumulate more wealth. For instance, the average financial wealth for those age 20-34 is about twice as large as the base case (2.1 times first-year labor income, instead of 1.1; Table 2). After age 60, when remaining work years dwindle and exposure to labor income risk becomes less important, individuals use their relatively high saving to reduce work hours and enjoy more leisure. As shown in Table 3, households with higher risk aversion retire at age 63.1 on average, or about 8.5 months earlier than the reference case (age 63.8). Compared to the base case, the secondary retirement peak at age 65 reported by previous empirical studies no longer is evident. The mean consumption drop at retirement for the highly riskaverse individuals is the same as the reference case (Table 4, column 2). Not surprisingly, more risk-averse individuals exit equities in favor of bonds and annuities at much younger ages (Table 2, column 2).

For individuals with a bequest motive (Case 5), the results of work hours, retirement ages, and consumption drops are comparable to those in the reference case, showing that introducing bequests does not much influence labor supply and retirement behavior. The bequest motive does induce older individuals to accumulate more inheritable financial wealth in terms of equity and bonds, while the allocation to illiquid life annuities is lower.

Changing the leisure parameters does have a more potent impact on labor supply, retirement behavior, consumption, and investment decisions. Reducing the leisure parameter from 1.3 to 0.9 (Case 4) results in an extraordinarily high level of work effort over the lifecycle, in that young and middle-age employees are predicted to work at least 50 hours per week. Many of them must even be required to retire by age 69 and accept a relatively high consumption decline at retirement. Accordingly, this functional form might be most relevant to tenured university professors (as noted by Ashenfelter and Card 2002), but not for the majority of the population. Asset allocation for this group seems reasonable in that they accumulate substantial financial wealth beginning with a high equity allocation and, with age, gradually moving into safer investments like bonds and annuities. Yet it must be recalled that this intuitively appealing life-cycle investment profile coincides with a very intensive and lengthy worklife, a pattern limited to relatively few.

The model with an age-dependent utility of leisure parameter (Case 3) also results in the young and middle-aged workers taking on very high labor hour commitments (averaging 50 hours per week to age 40), while their effort drops off as health problems set in. 
Additionally, they are likely to retire very early, with about half leaving work at age 62. Now, however, the second retirement peak at age 65 disappears, in contrast to the empirical results reported by Gustman and Steinmeier (2005). Such households who anticipate the age/healthrelated importance of leisure in later life save more and invest in less risky portfolios before retirement, compared to the base case. Consequently, the higher accumulated assets allow them to have a smaller consumption drop at retirement.

Capital Market Parameters: Introducing a positive correlation between the shocks to permanent labor income and stock market returns has a slightly increasing effect on work effort (Case 6). Work hours for all age groups are moderately higher compared to the reference case. Retirement from full-time work occurs, on average, half a year later (age 64.4 versus 63.8). Further, such households accept a greater drop in consumption at retirement ($24.2 \%$ versus $-19.1 \%$ ). This result is driven by the well-known fact that a positive correlation between stock and labor market shocks forces households to invest less risky (see Cocco, Gomes, Maenhout 2005). The smaller asset base resulting from a safer portfolio provides less with which to finance reduced work hours and earlier retirement, and buffer consumption declines at retirement.

Consistent with that line of argumentation, a higher equity risk premium (Case 7) enhances the allocation towards stocks. As a result, expected asset accumulations at the end of work-life are higher, allowing the individual to retire earlier (on average at age 63.2 versus $63.8)$ and experience a smaller consumption drop (-12.7\% versus $-19.1 \%)$ compared with the base case. Overall, the variations of capital market parameters considered here have small effects on work hours and retirement behavior, but noticeable impacts on portfolio decisions.

Increasing the Full Claiming Age (FCA) for Social Security Benefits: The final robustness check is a situation when full benefits from Social Security are only available two years later $(F C A=67)$. Such an increase makes the early claiming of Social Security benefits more costly for the individual, because of the higher actuarial reduction factor. In this setting, work hours for the young and middle-aged workers are similar to those in the reference case, but important impacts appear later in life. Individuals work more hours in their $60 \mathrm{~s}$, and the average retirement age increases to almost age 67. The drop in consumption now averages $24.5 \%$. Turning to asset allocation, individuals save more in the later part of their working lives and reduce their allocation to equities in favor of life annuities. This helps compensate for reduced Social Security benefits.

\section{Welfare Analysis}


Our model shows that household optimal consumption and leisure patterns over the life-cycle are powerfully shaped by labor supply flexibility, choice of retirement age, access to capital markets, and the availability of longevity risk insurance via life annuities. Moreover, our base-case model tracks some important empirical stylized facts, including the two peaks observed in retirement ages, the hump-shaped pattern of work hours, a discontinuity in consumption at retirement, and low annuity take-ups by older households. Yet the model's normative predictions of high and then decreasing stock fractions for young and middle-aged workers differs notably from observed behavior, namely relatively low and constant equity/bond mixes. Thus it is of interest to examine the economic importance of having less labor market flexibility, market incompleteness, and inertial household financial decisionmaking. In addition, our framework allows us to study the welfare implications of recent product innovations offered by the retirement finance industry. One such innovation is the development of variable (investment-linked) payout annuities which allow the annuitant to participate in the equity risk premium.

Table 6 quantifies the impact on consumer welfare in two ways: relative utility gains based on standard consumption-equivalent variations, and also gains relative to what the consumer would be willing to give up as a percent of her first-year labor earnings. ${ }^{30}$ These increases in lifetime utility are computed from the vantage point of a 20 -year old. Welfare gains are computed for a simple reference case given the lifetime utility level of a consumer with fixed work hours and retirement date, and who also lacks access to annuity markets (Row A). ${ }^{31}$

\section{Table 6 here}

As noted before, many people can optimize their work effort and consumption as in the model. But in the real world, they may fail to optimally allocate their assets and instead adopt a simple constant portfolio mix strategy. To better understand these behaviors, and to explore the potential impact of this suboptimal investment behavior, we introduce Rows (B) and (C). Relative to the reference case, the worker in Row (B) invests assets using a constant 60:40 equity/bond investment rule. This suboptimal asset allocation is shown to produce a relatively low lifelong utility loss of $0.5 \%$ (measured in consumption-equivalent terms), or a $3.2 \%$ loss of first-year labor income. Row (C) depicts an individual who can adapt both her work hours and her Social Security claiming age; this additional freedom with respect to her labor market options provides a large lifetime utility gain of $8.2 \%$, or a $61 \%$ gain in first-year

\footnotetext{
${ }^{30}$ Computational details appear in the Technical Appendix A.

${ }^{31}$ The consumption-equivalent variable in utility terms is a standard metric; we also present the worker's first year of labor income as a metric for the welfare change as in Gomes, Kotlikoff, and Viceira (2008).
} 
labor income. Comparing Row (B) and (C), we conclude that a highly restrictive labor market in terms of fixed work hours and claiming ages is less appealing than having a suboptimal asset allocation. This may be one reason why people tend not to pay much attention to their asset allocations although they may optimize work hours and claiming ages.

Rows (D) and (E) permit flexible hours, endogenous claiming ages, and optimal portfolio decisions; we also add payout annuities to the investment opportunity set. In Row (D), only fixed annuities are available. Given labor market flexibility, the additional utility gains of $0.1 \%$ are very low in a world with fixed annuities, as compared one without annuities (Row C). This changes, however, if the worker has access to investment-linked payout annuities. In this most flexible case, reported in Row (E), lifetime utility rises by $9.6 \%$ compared to the reference case, or $1.4 \%$ more than a world without annuities (Row C). It is interesting to note that fixed payout annuities have been virtually the only product available in the US until recently, with variable (investment-linked) payout annuities being a recent market entrant. Nevertheless, the evident appeal of variable payout products in our model implies that these may become more attractive as the population ages.

Evidently there is a substantial utility benefit from labor market flexibility in the form of adjustable weekly hours of work and claiming ages. By contrast, the utility cost is relatively low due to suboptimal investing according to the well-known 60:40 equity-to-bond rule. Nevertheless, it is non-negligible, suggesting that it may be attractive to enhance investor decision-making by improving financial literacy and by providing more appealing financial products. Having access to fixed annuities is also advantageous, but less important than variable payout annuities from the vantage point of a labor market entrant. 


\section{Conclusions}

We integrate the literatures on retirement saving, portfolio choice, and labor supply with a model of endogenous life-cycle consumption, saving, work hours, retirement age, and investment patterns, where the consumer has access to both the capital market (stocks and bonds) and payout annuities. Our model, with realistically calibrated parameters, can track key stylized facts like the two peaks in retirement rates, the hump-shaped pattern of work hours, and the low annuity take-ups of older households to a reasonable extent. Furthermore, by introducing endogenous work hours and claiming dates, we derive optimal consumption paths in which consumers are found to endogenously reduce their expenditure levels around the time of retirement, suggesting that the so-called 'consumption puzzle' described by some analysts may, in fact, not be a puzzle at all.

Our model also shows how individuals can optimally adjust both their financial portfolios and their work effort in response to both capital and labor market shocks. Prior models have not incorporated this degree of interaction between labor, consumption, capital, and annuity markets, yet it proves to make a difference. For example, a positive permanent wage rate shock early in life and below-average capital market returns combine to produce higher work hours, later retirement, and larger consumption drops at retirement, as well as low reliance on annuities. Conversely, a worker lucky enough to earn high equity returns can retire early and have much smaller consumption drop at retirement, even if she experiences a negative labor market shock; the additional capital income is used to buy annuities to supplement her low (earnings-related) Social Security benefits.

Moreover, we show that making work hours and claiming dates flexible substantially enhances lifetime welfare for the young, while the utility cost of following fixed 60:40 equityto-bond rule are small. On the one hand, this could be a reason why many households do not devote much attention to managing their investment portfolios, although they do optimize their work hours and claiming date. On the other hand, there remains a non-negligible utility loss from not optimizing the investment mix, so improving financial literacy and providing more favorable financial products would be beneficial. Utility gains from traditional fixed annuities are small, but utility is enhanced with investment-linked payout annuities, a recent innovation in the retirement finance industry.

In sum, combining work, investment, and lifetime payouts can provide better and more attractive ways to manage life's many challenges. Though fixed payout annuities have been prevalent in the marketplace to date, we anticipate that investment-linked payout annuities will become more popular as Baby Boomers age and Social Security benefits will fail to 
grow. 


\section{References}

Aguiar, M. and E. Hurst (2005). Consumption vs. Expenditure. Journal of Political Economy. October 113, 919-948.

Amromin, G. (2003). Household Portfolio Choices in Taxable and Tax-Deferred Accounts: Another Puzzle? European Finance Review 7, 547-582.

Ashenfelter, O. and D. Card. (2002). Did the Elimination of Mandatory Retirement Affect Faculty Retirement? American Economic Review 92, 957-980.

Banks, James, Richard Blundell, and Sarah Tanner (1998). Is There a Retirement-Savings Puzzle? American Economic Review 88, 769-88.

Battistin, E., A. Brugiavini, E. Rettore, and G. Weber. (2009). The Retirement Consumption Puzzle: Evidence from a Regression Discontinuity Approach. American Economic Review 99, 2209-26.

Bernheim, D., A. Shleifer, and L. Summers, (1985). The Strategic Bequest Motive. The Journal of Political Economy 93, 1045-1076.

Bernheim, B. D., Jonathan Skinner and Steven Weinberg (2001). What Accounts for the Variation in Retirement Wealth among U.S. Households? American Economic Review 91, 832-857.

Benítez-Silva, H. and F. Heiland (2008). Early Claiming of Social Security Benefits and Labor Supply Behavior of Older Americans. Applied Economics, Taylor and Francis Journals 40, 2969-2985.

Benzoni, L., R. Collin-Dufresne, and R. Goldstein (2007). Portfolio Choice Over the Life Cycle When the Stock and Labor Markets are Cointegrated. Journal of Finance 64, 2123-2167.

Blundell, R. and T. MaCurdy (1999). Labor Supply: A Review of Alternative Approaches. O. Ashenfelter and D. Card (eds.), Handbook of Labor Economics (3A), Amsterdam: Elsevier North Holland, 1559-1695.

Bodie, Z., R. Merton, and W. Samuelson (1992). Labor Supply Flexibility and Portfolio Choice in a Life Cycle Model. Journal of Economic Dynamics and Control 16, 427449.

Bodie, Z., J.B. Detemple, S. Otruba, and S. Walter (2004). Optimal Consumption-portfolio Choices and Retirement Planning. Journal of Economic Dynamics and Control 28, 1115-1148.

Bodie, Z., J.B. Detemple, and M. Rindisbacher (2009). Life Cycle Finance and the Design of Pension Plans. Annual Review of Financial Economics. December 1,249-286.

Brown, J., O.S. Mitchell, J. Poterba, and M. Warshawsky (1999). Taxing Retirement Income: Nonqualified Annuities and Distributions from Qualified Accounts. National Tax Journal 52, 563-586.

Buchinsky, M, Rust, J., and Benítez-Silva, H (2000). Dynamic Structural Models of Retirement and Disability. Yale University Department of Economics Working Paper.

Campbell, J., J. Cocco, F. Gomes, and P. Maenhout (1999). Investing Retirement Wealth. A Life Cycle Model, In: John Campbell and Martin Feldstein (Eds): Risk Aspects of Social Security Reform, University of Chicago Press, Chicago, 439-482.

Campbell, J. and L. Viceira (2001). Who Should Buy Long-Term Bonds? American Economic Review 91, 99-127.

Cocco, J., F. Gomes, and P. Maenhout (2005). Consumption and Portfolio Choice over the Life Cycle. Review of Financial Studies 18, 491-533.

Coile, C. P.A. Diamond; J. Gruber, and A. Jouston (2002). Delays in Claiming Social Security Benefits. Journal of Public Economics 84, 357-385.

Cooley, T.F. and E.C. Prescott (1995): Economic Growth and Business Cycles. In: Cooley, Thomas F. (ed.), Frontiers of Business Cycle Research, Princeton, NJ: Princeton 
University Press, 1-38.

Diamond, Peter, and James Mirrlees (1978). A Model of Social Insurance with Variable Retirement. Journal of Public Economics 10 3, 295-336.

Farhi, E. and Panageas, S. (2007). Saving and Investing for Early Retirement: A Theoretical Analysis. Journal of Financial Economics 83, 87-121.

Fehr, H., S. Jokisch, and L.J. Kotlikoff (2006). Will China Eat our Lunch or Take Us Out to Dinner? Simulating the Transition Paths of the US, EU, Japan and China. In: Takatoshi I. and A. K. Rose (Eds.), Fiscal Policy and Management in East Asia. Chicago, University of Chicago Press: 133-198.

Fields, G. S. and O. S. Mitchell (1984). Retirement, Pensions, and Social Security. Cambridge, Mass.: MIT Press.

French, E. (2005). The Effects of Health, Wealth, and Wages on Labor Supply and Retirement Behaviour. Review of Economic Studies 72, 395-427.

Gruber, Jonathan and David Wise. (2004). Social Security Programs and Retirement around the World: Micro-Estimation. Chicago: University of Chicago and NBER.

Gomes, F., L. Kotlikoff, and L.M. Viceira (2008). Optimal Life-Cycle Investing with Flexible Labor Supply: A Welfare Analysis of Life-Cycle Funds. American Economic Review: Papers \& Proceedings 98, 297-303.

Gomes, F., and A. Michaelides (2005). Optimal Life-Cycle Asset Allocation: Understanding the Empirical Evidence. Journal of Finance 60, 869-904.

Gustman, A. L. and T. L. Steinmeier (2005). The Social Security Early Entitlement Age in a Structural Model of Retirement and Wealth. Journal of Public Economics 89, 441463.

Gustman, A. L., T. L. Steinmeier, and N.Tabatabai (2010). What the Stock Market Decline Means for the Financial Security and Retirement Choices of the Near-Retirement Population. Journal of Economic Perspectives. 24, 161-182.

Heaton, J. and D. Lucas (1997). Market Frictions, Savings and Portfolio Choice. Macroeconomic Dynamics 1, 76-101.

Horneff, W., R. Maurer, O.S. Mitchell, and I. Dus (2008). Following the Rules: Integrating Asset Allocation and Annuitization in Retirement Portfolios. Insurance: Mathematics and Economics 42, 396-408.

Horneff, W., R. Maurer, and M. Stamos (2008). Life-Cycle Asset Allocation with Annuity Markets. Journal of Economic Dynamics and Control 32, 3590-3612.

Horneff, W., R. Maurer, O.S. Mitchell, and M. Stamos (2009). Asset Allocation and Location Over the Life Cycle With Survival Contingent Payouts. Journal of Banking and Finance 33, 1688-1699.

Horneff, W., R. Maurer, O.S Mitchell, and M. Stamos (2010). Variable Payout Annuities and Dynamic Portfolio Choice in Retirement. Journal of Pension Economics and Finance 9, 163-183

Hurd, M. (1989). Mortality Risk and Bequest. Econometrica 57, 779-813.

King, R, C. Plosser, and S. Rebelo (1988). Production, Growth and Business Cycles: I. The Basic Neoclassical Model," Journal of Monetary Economics 21, 195-232.

Inkmann, J., P. Lopes, and A. Michaelides (2011). How Deep Is the Annuity Market Participation Puzzle? Forthcoming: Review of Financial Studies 18, 491-533

Laitner, J. P. (2003). Labor Supply Responses to Social Security. Michigan Retirement Research Center Research Paper No. WP 2003-050.

Low, H. (2005). Self-insurance in a Life-cycle Model of Labor Supply and Savings. Review of Economic Dynamics 8, 945-975.

Lusardi, A. and O.S. Mitchell (2007). Baby Boomers Retirement Security: The Roles of Planing, Financial Literacy, and Housing Wealth. Journal of Monetary Economics 54, 205-224. 
Malkiel, B. G. (1996). A Random Walk Down Wall Street: Including a Life-Cycle Guide to Personal Investing (6th ed.), Norton, New York.

Merton, Robert C. (1969). Lifetime Portfolio Selection under Uncertainty: The ContinuousTime Case. Review of Economics and Statistics 51, 247-257.

Milevsky, M. (2006). The Calculus of Retirement Income: Financial Models for Pension Annuities and Life Insurance. Cambridge: Cambridge University Press.

Milevsky, M., K. Moore, and V. Young (2006). Asset Allocation and Annuity-Purchase Strategies to Minimize The Probability of Financial Ruin. Mathematical Finance 16, 647-671.

Milevsky, M. and V. Young (2007). Annuitization and Asset Allocation. Journal of Economic Dynamics and Control 31, 3138-3177.

Mitchell, O.S. and J. Phillips (2006). Social Security Replacement Rates for Alternative Earnings Benchmarks. Benefits Quarterly 4, 37-47.

Polkovnichenko, V. (2007). Life-Cycle Portfolio Choice with Additive Habit Formation Preferences and Uninsurable Labor Income Risk. Review of Financial Studies 20, 83124.

Samwick, A. (1998). Discount Rate Heterogeneity and Social Security Reform. Journal of Development Economics 57, 117-146.

Viceira, L. (2001). Optimal Portfolio Choice for Long-Horizon Investors with Non-tradable Labor Income. Journal of Finance 56, 433-470.

Yaari, M. E. (1965). Uncertain Lifetime, Life Insurance, and the Theory of the Consumer. Review of Economic Studies 32, 137-150.

Yogo, M. (2009). Portfolio Choice in Retirement: Health Risk and the Demand for Annuities, Housing and Risky Assets. NBER W15307 (September 2009).

U.S. Department of Labor (2010). American Time Use Survey Summary. Bureau of Labor Statistics. http://www.bls.gov/news.release/atus.nr0.htm

U.S. Social Security Administration (2010). Income of the Population 55 or Older, 2008. Office of Policy. Washington, D.C.

http://www.ssa.gov/policy/docs/statcomps/income_pop55/2008/sect10.html\#table10.1(Viewed 31.3.11) 


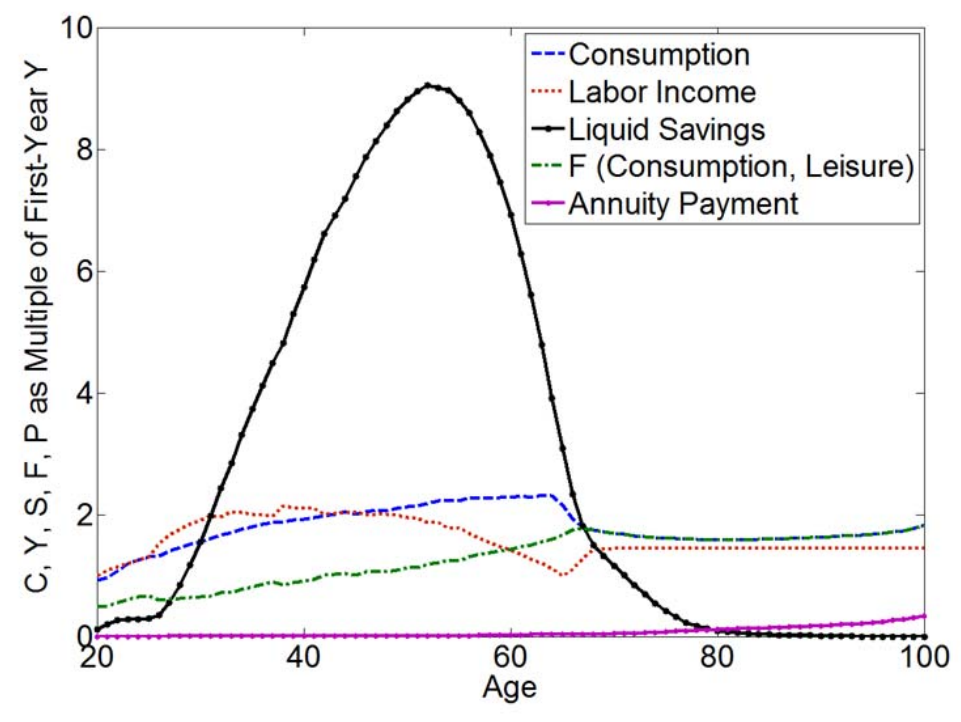

\section{A. Life-Cycle Patterns}

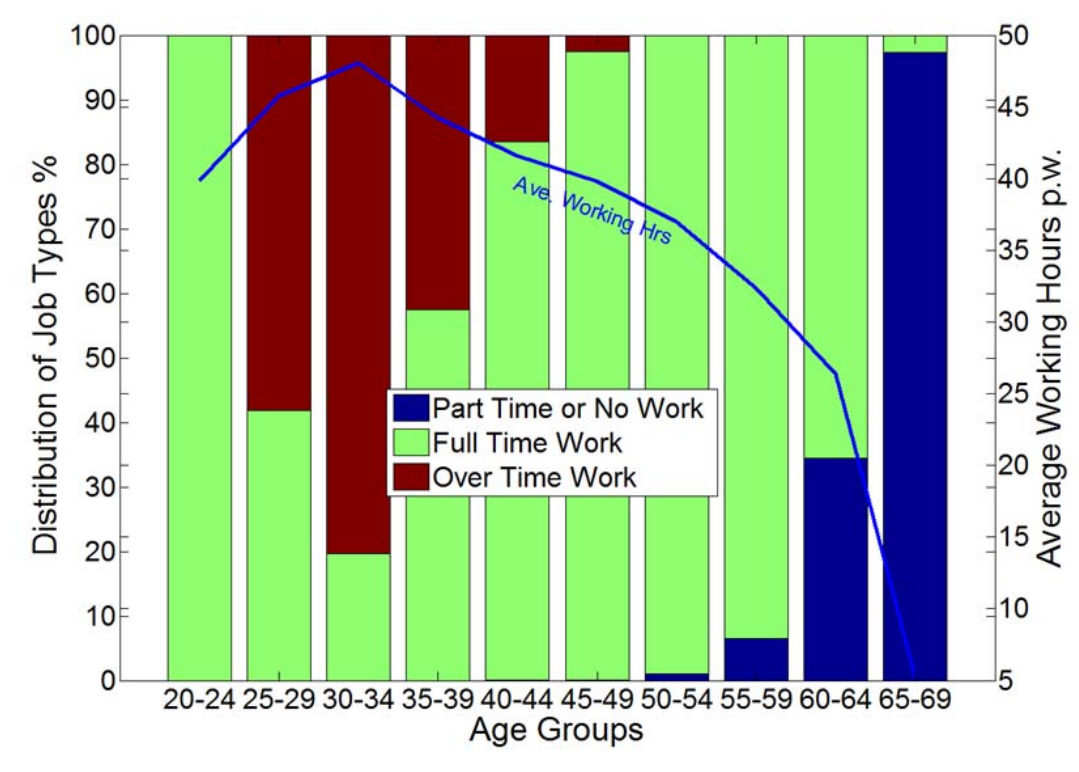

1B. Work Hours Patterns

Figure 1: Optimal Life-Cycle and Work Hours Patterns: Panel 1A displays expected consumption $C$, saving in liquid assets $S$, labor income $Y$, and annuity payments $P$, all as a multiple of first-year labor earnings over the life-cycle. We also show the Cobb-Douglas function value $F=\mathrm{CL}^{\alpha}$. In Panel 1B, the blue line displays average work hours per week for different groups from age 20 until 70 (the oldest feasible retirement age) and the bars plots the distribution of work hours classified according to: overtime [50, 60 work hours per week], full-time [30, 40 work hours per week], and part-time or no work [0, 10, 20 work hours per week]).

Notes: The household has a moderate level of risk aversion for consumption $\rho$ of 5 , a discount rate $\beta$ of 0.97 , and the leisure preference parameter $\alpha$ is 1.3. The correlation between stock returns and permanent earnings shocks $\phi_{\mathrm{n}}$ is set to zero and the equity risk premium $3 \%$. Fixed payout annuities are priced using the US annuitant 2000 mortality table $(A I R=2 \%$, loading factor 1.0238$)$. We use optimal feedback controls obtained from the stochastic optimization for a female with a maximum lifespan of age 100; expectations are computed from 10,000 Monte Carlo simulations path based on the optimal policies derived by the numerical optimization. 


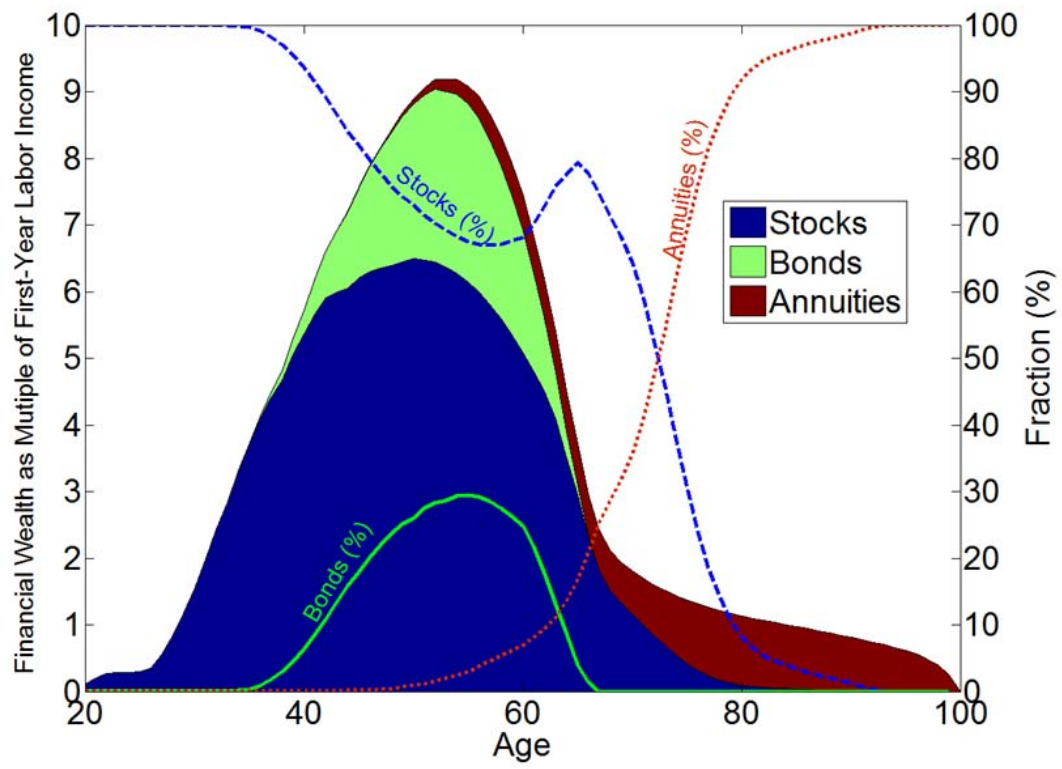

Figure 2: Financial Wealth and Asset Allocation Patterns by Age. The Figure depicts expected amounts invested in stocks, bonds, and fixed payout annuities (as a multiple of first year labor income) and trajectories for the fraction held in liquid stocks, bonds, and fixed annuities. Asset weights are reported in percent of total wealth (liquid wealth + present value of annuity claims). 


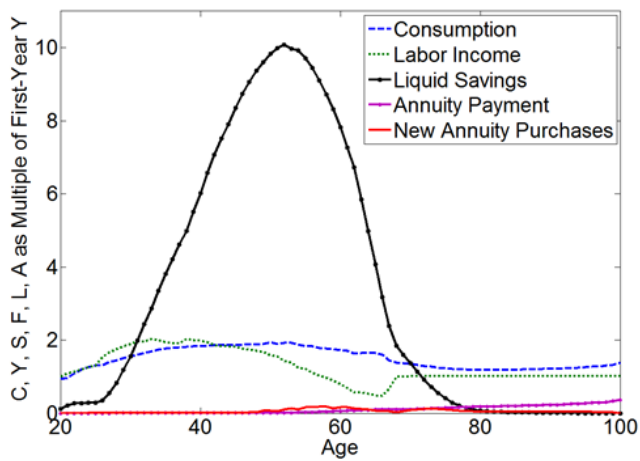

3A. Life-Cycle Pattern for Individuals Retiring at Age 62

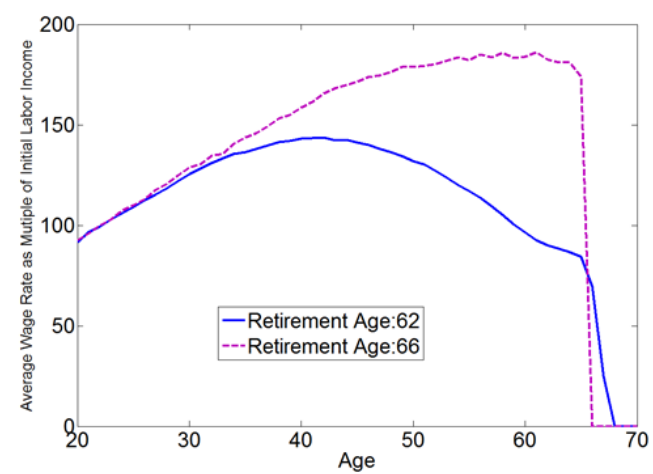

3C. Average Wage Rate for Individuals Retiring at Age 62 (66)

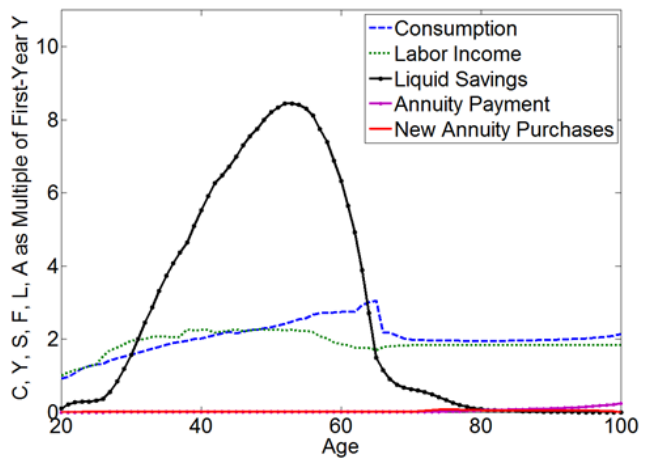

3B. Life-Cycle Pattern for Individuals Retiring at Age 66

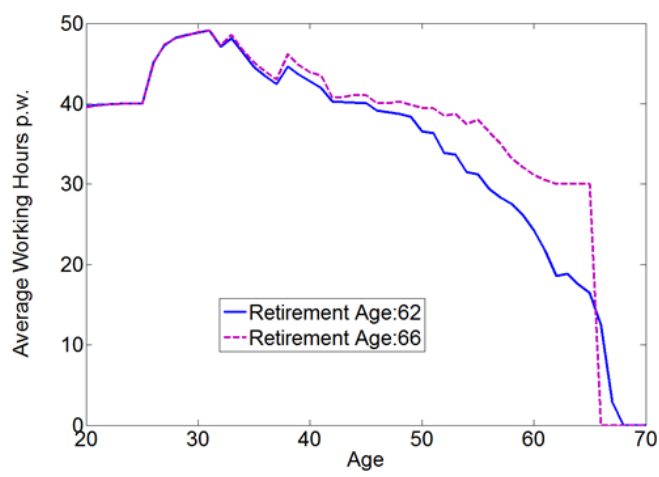

$3 D$. Average Weekly Hours for Individuals Retiring at Age 62 (66)

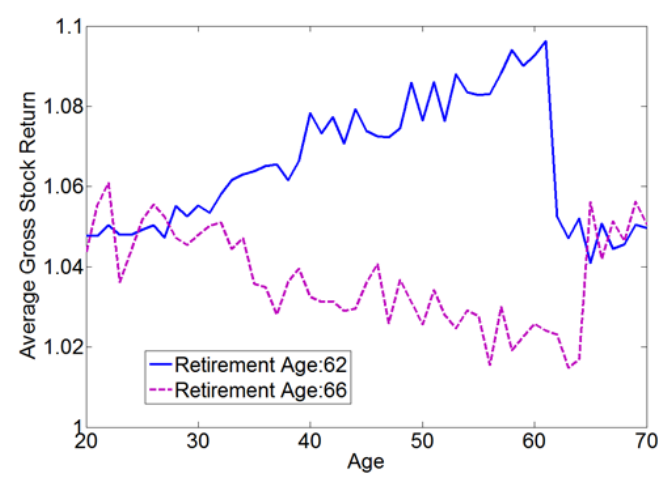

3E. Average Gross Stock Returns for Individuals Retiring at Age 62 (66)

Figure 3: Expected Consumption, Work Hours, Wage Rates and Stock Return Patterns over the Life-Cycle for Those Who Retire at Age 62 and 66. Notes: See Figure 1. 


\begin{tabular}{|c|c|c|c|c|c|c|c|}
\hline \multirow[t]{2}{*}{ Age } & $\begin{array}{c}\text { Claiming } \\
\text { Rate }\end{array}$ & $\begin{array}{c}\text { Retirement } \\
\text { Rate }\end{array}$ & $\begin{array}{c}\text { Expected Change } \\
\text { in log average } \\
\text { Consumption }\end{array}$ & & & & \\
\hline & \multicolumn{3}{|c|}{$\begin{array}{c}\%) \\
\end{array}$} & & & & \\
\hline 62 & 0 & 33.1 & -5.0 & \multirow{3}{*}{\multicolumn{4}{|c|}{ Change in log average Consumption at Retirement (\%) }} \\
\hline 63 & 0 & 8.9 & -8.7 & & & & \\
\hline 64 & 1.4 & 14.8 & -15.0 & & & & \\
\hline 65 & 13.8 & 30.1 & -32.8 & \multirow{2}{*}{\multicolumn{2}{|c|}{ Full Sample }} & \multicolumn{2}{|l|}{ Subsample } \\
\hline 66 & 37.5 & 13.1 & -35.3 & & & Wealth at Retirement & Mean \\
\hline 67 & 31.4 & 0 & - & Mean & -19.1 & 1. Quartile & -35.0 \\
\hline 68 & 15.9 & 0 & - & Median & -20.3 & 2. Quartile & -21.8 \\
\hline 69 & 0 & 0 & - & St.Dev. & 18.9 & 3. Quartile & -12.2 \\
\hline 70 & 0 & 0 & - & 5\% Quartile & -48.1 & 4. Quartile & -7.5 \\
\hline Ave. & 66.47 & 63.81 & -19.1 & & 13.2 & Correlation & 43.0 \\
\hline
\end{tabular}

Table 1: Claiming and Retirement Rates, and Change in Consumption at Retirement. Panel A reports the percent of households retiring from full-time jobs (working $\leq 20$ hours/week) as well as the percentage of households claiming Social Security benefits (working zero hours) at each age from 62 to 70. In addition, Panel A displays for each age group of retirees the difference in log average consumption between the two years after and prior to retirement. The change in log average consumption at retirement is defined as in Bernheim, Skinner, and Weinberg (2001). Panel B, left block, provides summary statistics for consumption change at retirement for all 10,000 simulated lifecycle profiles. The right block of Panel B shows the average consumption change at retirement by quartiles of liquid wealth at retirement. 
Average Work Hours per Week

\begin{tabular}{|c|c|c|c|c|c|c|c|c|}
\hline \multirow{4}{*}{ Age Groups } & \multirow{3}{*}{$\begin{array}{c}(1) \\
\end{array}$} & \multirow{3}{*}{$\begin{array}{c}(2) \\
\rho\end{array}$} & \multirow{2}{*}{ (3) } & & & & & \\
\hline & & & & (4) & (5) & (6) & (7) & $(8)$ \\
\hline & & & $\alpha$ & $\alpha$ & $b$ & $\phi_{n}$ & $E\left(R-R_{f}\right)$ & FCA \\
\hline & & 7 & vary & 0.9 & 2 & 0.2 & 0.05 & 67 \\
\hline $20-24$ & 39.9 & 44.7 & 49.3 & 49.3 & 39.8 & 39.9 & 39.9 & 39.9 \\
\hline $25-29$ & 45.8 & 49.0 & 50.0 & 54.1 & 45.7 & 47.6 & 43.8 & 47.4 \\
\hline $30-34$ & 48.0 & 46.7 & 50.0 & 56.0 & 47.3 & 48.8 & 46.0 & 47.6 \\
\hline $35-39$ & 44.3 & 43.7 & 49.5 & 53.9 & 44.8 & 44.5 & 43.4 & 44.9 \\
\hline $40-44$ & 41.6 & 41.0 & 45.6 & 51.4 & 41.8 & 41.6 & 41.2 & 41.9 \\
\hline $45-49$ & 39.8 & 39.6 & 40.8 & 49.7 & 39.7 & 40.0 & 39.5 & 40.0 \\
\hline $50-54$ & 36.9 & 37.1 & 36.4 & 47.5 & 37.2 & 38.6 & 37.0 & 37.9 \\
\hline $55-59$ & 32.3 & 31.5 & 30.9 & 42.8 & 32.3 & 32.8 & 32.4 & 33.2 \\
\hline $60-64$ & 26.3 & 23.3 & 23.9 & 36.7 & 25.9 & 27.8 & 25.3 & 27.2 \\
\hline $65-69$ & 5.2 & 2.0 & 5.3 & 20.9 & 4.4 & 5.2 & 3.3 & 9.9 \\
\hline
\end{tabular}

Table 2: Work Hours per Week over the Life-Cycle for Alternative Parameters. The Table displays average hours worked per week for eight parameter settings. Case (1) is the reference case with a modified Cobb-Douglas (MCD) utility function where leisure preferences are $\alpha=1.3$, the curvature parameter is $\rho=5$, and time preference $\beta=0.97$. The correlation between stock returns and permanent earnings shocks is $\phi_{\mathrm{N}}=0$ and the equity risk premium $\mathrm{E}\left(\mathrm{R}-\mathrm{R}_{\mathrm{f}}\right)=0.03$. For Case (2), the individual becomes more risk-averse so $\rho=7$. In Case (3) we use an age-dependent $\alpha$ to allow for a gradual decline in the utility of leisure associated with poorer health at older ages as in Buchinski et al. (2000). The $\alpha(t)$ is given by $\alpha=$ $1.9-1 /(1+t / 60)$, where $t$ is the period. Case (4) has $\alpha=0.9$, i.e. the investor prefers to have much less leisure time. Case (5) assumes the investor has a bequest motive (with $b=2$ ). For Case (6) we assume a correlation of $\phi_{\mathrm{n}}=0.2$ between labor and capital market shocks. Case (7) takes a higher equity premium with $\mathrm{E}\left(R-R_{f}\right)=5 \%$. For Case (8), we postpone the FCA (Full Claiming Age) to age 67. Notes: See Figure 1. 
Asset Allocation (\%) and Liquid Savings

\begin{tabular}{|c|c|c|c|c|c|c|c|c|c|}
\hline & & & & & & & & & \\
\hline & & $(1)$ & $(2)$ & (3) & (4) & (5) & (6) & (7) & (8) \\
\hline \multirow[t]{2}{*}{ Age } & & \multirow{2}{*}{ Base Case } & $\rho$ & $\alpha$ & $\alpha$ & $b$ & $\phi_{n}$ & $E\left(R-R_{f}\right)$ & FCA \\
\hline & & & 7 & vary & 0.9 & 2 & 0.2 & 0.05 & 67 \\
\hline \multirow{4}{*}{$20-34$} & Stocks \% & 99.9 & 92.2 & 99.4 & 99.8 & 99.6 & 85.4 & 100.0 & 99.9 \\
\hline & Bonds \% & 0.1 & 7.8 & 0.6 & 0.2 & 0.4 & 14.6 & 0.0 & 0.1 \\
\hline & Annuities \% & 0.0 & 0.0 & 0.0 & 0.0 & 0.0 & 0.0 & 0.0 & 0.0 \\
\hline & Liquid Savings & 1.1 & 2.1 & 1.4 & 1.3 & 1.2 & 1.2 & 1.1 & 1.2 \\
\hline \multirow{4}{*}{$35-49$} & Stocks \% & 86.2 & 55.0 & 76.8 & 83.9 & 84.5 & 47.7 & 98.0 & 84.4 \\
\hline & Bonds \% & 13.7 & 37.9 & 22.4 & 14.1 & 15.4 & 51.7 & 2.0 & 14.1 \\
\hline & Annuities \% & 0.2 & 7.1 & 0.8 & 2.1 & 0.1 & 0.6 & 0.0 & 1.6 \\
\hline & Liquid Savings & 6.4 & 8.5 & 7.9 & 7.3 & 6.8 & 6.1 & 6.2 & 6.9 \\
\hline \multirow{4}{*}{$50-64$} & Stocks \% & 69.7 & 43.8 & 60.2 & 62.7 & 66.1 & 37.3 & 89.4 & 64.6 \\
\hline & Bonds \% & 25.6 & 25.7 & 29.2 & 21.3 & 31.0 & 56.4 & 8.7 & 22.6 \\
\hline & Annuities \% & 4.7 & 30.5 & 10.6 & 16.1 & 2.8 & 6.3 & 1.9 & 12.8 \\
\hline & Liquid Savings & 7.9 & 9.4 & 9.1 & 10.4 & 8.7 & 7.1 & 9.4 & 9.2 \\
\hline \multirow{4}{*}{$65-79$} & Stocks \% & 56.0 & 27.6 & 45.2 & 40.5 & 71.7 & 52.9 & 75.3 & 43.0 \\
\hline & Bonds \% & 0.7 & 0.0 & 0.6 & 1.1 & 9.1 & 7.3 & 0.3 & 0.9 \\
\hline & Annuities \% & 43.4 & 72.4 & 54.2 & 58.4 & 19.2 & 39.8 & 24.3 & 56.1 \\
\hline & Liquid Savings & 1.8 & 3.3 & 2.3 & 3.6 & 3.3 & 1.1 & 2.2 & 2.6 \\
\hline \multirow{4}{*}{$80-94$} & Stocks \% & 3.3 & 1.2 & 2.4 & 2.1 & 36.5 & 5.5 & 6.3 & 1.8 \\
\hline & Bonds \% & 0.0 & 0.0 & 0.0 & 0.0 & 32.7 & 0.0 & 0.0 & 0.0 \\
\hline & Annuities \% & 96.7 & 98.8 & 97.6 & 97.9 & 30.7 & 94.5 & 93.7 & 98.2 \\
\hline & Liquid Savings & 0.9 & 1.5 & 1.0 & 1.6 & 2.5 & 0.4 & 0.4 & 1.0 \\
\hline
\end{tabular}

Table 3: Expected Asset Allocation and Liquid Savings (as Multiple of First-Year Labor Income) Patterns for Alternative Parameters. The Table shows the stock/bond/annuity fraction and the amount of liquid savings as a multiple of first-year labor income for different age groups, under the eight parameter settings described in Table 2. 
Retirement Ratio (\%)

\begin{tabular}{|c|c|c|c|c|c|c|c|c|}
\hline \multirow{3}{*}{ Age } & (1) & (2) & (3) & $(4)$ & (5) & (6) & (7) & $(8)$ \\
\hline & \multirow{2}{*}{ Base Case } & $\rho$ & $\alpha$ & $\alpha$ & $b$ & $\phi_{n}$ & $E\left(R-R_{f}\right)$ & FCA \\
\hline & & 7 & vary & 0.9 & 2 & 0.2 & 0.05 & 67 \\
\hline 62 & 33.1 & 40.2 & 49.5 & 4.2 & 28.8 & 18.3 & 47.7 & 3.8 \\
\hline 63 & 8.9 & 14.5 & 10.4 & 2.9 & 21.0 & 9.8 & 14.8 & 2.5 \\
\hline 64 & 14.8 & 39.7 & 12.8 & 3.9 & 13.3 & 18.2 & 10.0 & 2.1 \\
\hline 65 & 30.1 & 5.6 & 18.6 & 3.4 & 29.1 & 24.8 & 21.5 & 2.4 \\
\hline 66 & 13.1 & 0 & 8.6 & 3.5 & 7.9 & 28.9 & 6.0 & 23.6 \\
\hline 67 & 0 & 0 & 0 & 9.6 & 0 & 0 & 0 & 18.4 \\
\hline 68 & 0 & 0 & 0 & 43.0 & 0 & 0 & 0 & 47.3 \\
\hline 69 & 0 & 0 & 0 & 29.5 & 0 & 0 & 0 & 0 \\
\hline 70 & 0 & 0 & 0 & 0 & 0 & 0 & 0 & 0 \\
\hline mean & 63.8 & 63.1 & 63.3 & 67.5 & 63.7 & 64.4 & 63.2 & 66.8 \\
\hline
\end{tabular}

Table 4: Retirement Rates for Alternative Parameters. The Table reports the percent of people retiring at each age from 62 to 70 under the eight alternative parameter settings described in Table 2 . 
Expected Change in log Average Consumption (\%)

\begin{tabular}{|c|c|c|c|c|c|c|c|c|}
\hline \multirow{3}{*}{ Age } & (1) & (2) & (3) & (4) & (5) & (6) & (7) & (8) \\
\hline & \multirow{2}{*}{ Base Case } & $\rho$ & $\alpha$ & $\alpha$ & $b$ & $\phi n$ & $\mathrm{E}(\mathrm{R}-\mathrm{R} f)$ & FCA \\
\hline & & 7 & vary & 0.9 & 2 & 0.2 & 0.05 & 67 \\
\hline 63 & -8.7 & -15.3 & -8.9 & -8.8 & -7.6 & -12.6 & -4.7 & -10.4 \\
\hline 64 & -15.0 & -31.4 & -13.9 & -8.5 & -28.2 & -17.1 & -29.4 & -13.4 \\
\hline 66 & -35.3 & - & -35.5 & -11.4 & -33.5 & -35.7 & -32.1 & -31.7 \\
\hline 67 & - & - & - & -26.4 & - & - & - & -28.7 \\
\hline 68 & - & - & - & -30.6 & - & - & - & -22.5 \\
\hline 69 & - & - & - & -23.6 & - & - & - & - \\
\hline 70 & - & - & - & - & - & - & - & - \\
\hline
\end{tabular}

Table 5: Expected Change in log Average Consumption at Retirement for Alternative Parameters. The Table reports the percent difference in $\log$ average consumption for the two years after and prior to retirement for the eight alternative parameter settings described in Table 2 . 


\begin{tabular}{|c|c|c|c|}
\hline \multicolumn{3}{|c|}{ Welfare Analysis } & Welfare \\
\hline \multicolumn{2}{|c|}{5 Cases } & \multirow{3}{*}{$\begin{array}{c}\text { Relative } \\
\text { Utility } \\
\text { Gains }\end{array}$} & \multirow{3}{*}{$\begin{array}{c}\text { Gain: \% of } \\
\text { 1st yr } \\
\text { Labor }\end{array}$} \\
\hline Labor & Annuity & & \\
\hline Market & Market & & \\
\hline (A) Fixed & No & Reference & Reference \\
\hline (B) Fixed & No (60\% Stocks) & $-0.5 \%$ & $-3.2 \%$ \\
\hline (C) Flexible & No & $8.2 \%$ & $61.0 \%$ \\
\hline (D) Flexible & Fixed & $8.3 \%$ & $61.1 \%$ \\
\hline (E) Flexible & Variable & $9.6 \%$ & $63.4 \%$ \\
\hline
\end{tabular}

Table 6: Welfare Analysis. We report utility gains as consumption-equivalent variations computed with reference to Row (A) which refers to the lifetime utility level of a consumer at age 20 without flexibility in labor market, i.e. fixed 40 hours of work/week, a fixed Social Security claiming age of 65 , and no access to annuity markets. In Row (B), we rule out endogenous asset allocation and assume the portfolio is set at a constant 60:40 stock/bond mix over the life-cycle. Compared to Row (A), Rows (C, D, and E ) have complete flexibility in labor market and allow the worker to select work hours and claiming ages, but they differ with regard to annuity possibilities. In Rows (D and E), we allow the access to annuities; in Row D, fixed annuities are available, and in Row E, variable investment-linked annuities are available. The last column reports the fraction of the worker's first year labor income that would be exchanged for the additional lifetime flexibility make him indifferent, relative to the reference case. Notes: See Figure 1. 


\section{Appendix A: Calculating the Utility-Constant Equivalent Consumption Stream (CE)}

For each case, the expected lifetime utility from consumption and leisure at $\mathrm{t}=1$ is given by:

$V_{1}=E_{1}\left(\sum_{t=1}^{T=81} \beta^{t-1}\left(\prod_{i=1}^{t} p_{i}^{s}\right) \frac{\left(C_{t} L_{t}^{\alpha}\right)^{1-\rho}}{1-\rho}\right)$,

where $\mathrm{C}_{t}$ and $\mathrm{L}_{t}$ are optimized in each model variant. In each case, we calculate the constant consumption stream CE for an investor with fixed work hours who claims Social Security benefits at age $65(F C A=65)$ and who does not have access to annuities (i.e. Row A in Table 6). This constant consumption stream CE makes her as well-off in expected utility terms at age 20 as the leisure and consumption stream that can be financed by the life-cycle strategy. $\mathrm{CE}$ is defined as follows:

$$
\begin{aligned}
& V_{1}=\sum_{t=1}^{K-1=45} \beta^{t-1}\left(\prod_{i=1}^{t} p_{i}^{s}\right) \frac{\left(C E L_{w l}^{\alpha}\right)^{1-\rho}}{1-\rho}+\sum_{t=K=46}^{T=81} \beta^{t-1}\left(\prod_{i=1}^{t} p_{i}^{s}\right) \frac{\left(C E 1^{\alpha}\right)^{1-\rho}}{1-\rho} \\
& \Rightarrow C E=\left[\frac{V_{1}(1-\rho)}{\sum_{t=1}^{K-1=45} \beta^{t-1}\left(\prod_{i=1}^{t} p_{i}^{s}\right) L_{w l}^{\alpha(1-\rho)}+\sum_{t=k=46}^{T=81} \beta^{t-1}\left(\prod_{i=1}^{t} p_{i}^{s}\right)}\right]^{\frac{1}{(1-\rho)}}
\end{aligned}
$$


Appendix B: Average Work Hours by the Panel Study of Income Dynamics (PSID) and Model Prediction

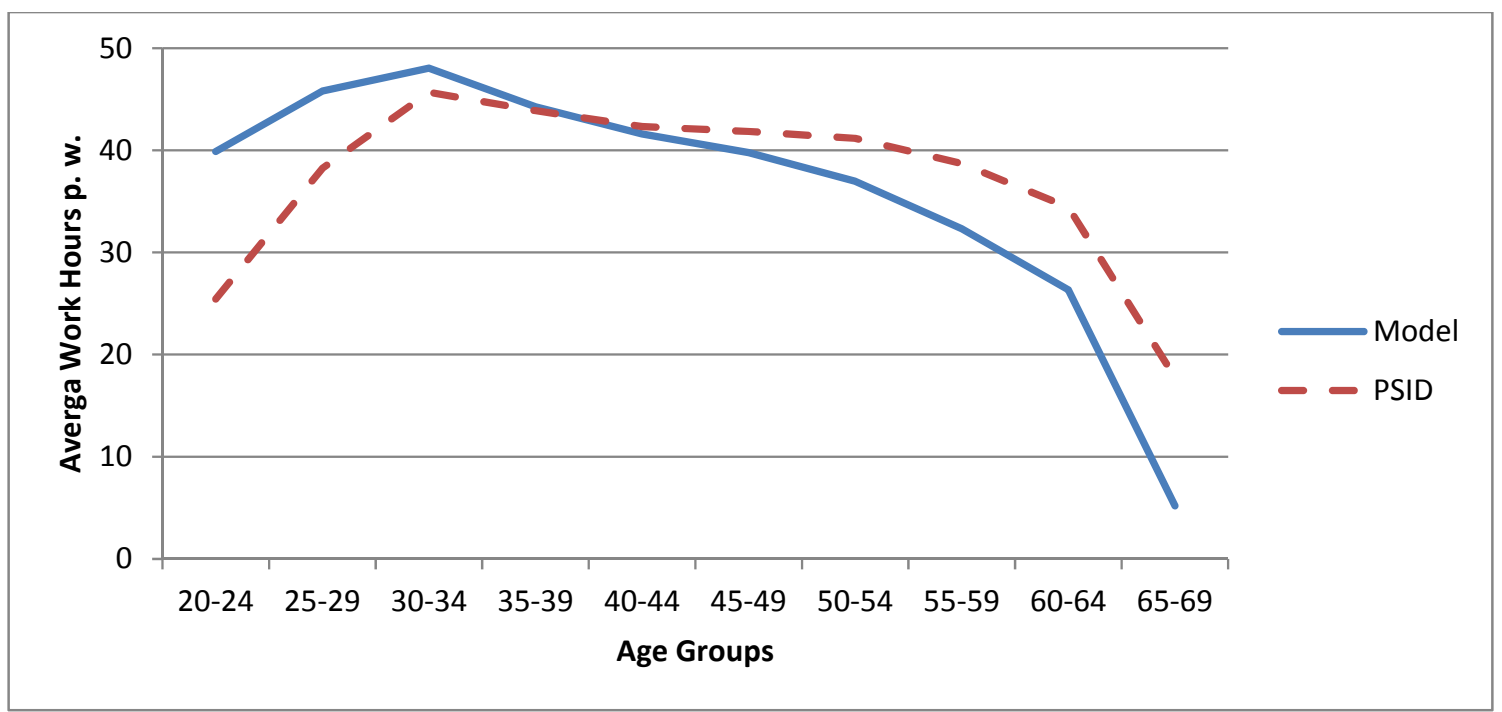

This Figure traces average weekly hours worked per week by age from our model in the base case (solid line), versus empirical evidence from the 2006 PSID (dashed line). We compute the PSID values for middle-income workers (annual income US\$ 25,000-100,000); mean weekly work hours for these workers are calculated by dividing yearly work hours by 52 weeks. 